\title{
SOBRE A INCAPACIDADE DOS MENORES NO DIREITO CIVIL E A SUA JUSTIFICAÇ̃̃̂́
}

\author{
Raul Guichard \\ ralguichard a yahoo.es
}

As" «descosidas» considerageres que ora se däo a lume constituem o simples retocar de um pequeno e já distante artigo, escrito na conclusão da licenciatura e incluído mais tarde na RDE- Revista de Direito - Economia. Ano XV. 1989, págs. 359 e s. Cuja publicacáo de novo talver se justifique, mesmo que só em parte actualizado e sobrecarregado com um dédalo de notas. Comquanto - o antor é o printeiro a reconlecế-lo - importasse repensá-lo por inteiro, sobretudo à luz das conceperoes hodiernas sobre o direito dos menores.

Na verdade, o «problema dos menores» ou, mais latamente, de quem ainda se encontra num «estádio de anadurecimento ou desenvolvimento» (cfr. art. 1880." do Código Civil CC, eart. 63.", n."1, da Lei n." 147/99, de 1/09 - Lei de Protecräo de Criangas e Jovens em Perigo) năo se confina à perspectiva aqui quase exclasivamente adoplada, mas que ainda serve, em grande parte, como pano de fundo ao regine da nossa lei civil: a da incapacidade em vista da pratica de actos juridicos-negociais, sobretudo de carácter patrinonial, e a do poder de representagăo e de administraçäo detido pelos pais ou pelos tutores.

Demais, não se poderia prescindir de apurar em que medida as concretas restrigóses à capacidade dos menores, abstraindo jó da consagraça genérica da «regras da sua incapacidade, se conciliam com. os direitos fundancentais à capacidade juridica e ao desenvolvimento da personalidade (art. 26.", m."s / e 4, da Constituição da República Portuguesa . CRP), com o principio da igualdade e da proporcionalidade, maxime no que este aqui implica de "proibicão de excessos". "Cfr. ainda, no encutadramento constitucional do dircifo das crianças e dos jovens, no âm-
bito da lamólia, arts. 36.", n."s 4, 5, 6 6 7, e 67." da CRP. Quanto à protecçăo especialmento 
Com efeito, e a esha laz, o menor näo deve ser consideralo como mero objecto de proteçäo, mas sim como sujeito de direilos".

Indispulada é hoje a preeninência da prolecena do bem(-estar)e da promogäo do desenvolvimento integral do menor (cifr., desde logo, art. I. da lei de Protecgän de Criancas e Jovens em Perigo e arts. 1973."e 1074." do CC, sobre a adop(äa). Neste fio de pensamento, falca-se sugestivamente de um favor minoris"ii. E como marco ma evolasão operada, assume lugar de particular destaque a Comvengäo das Naçöes Unidas sobre os Direilos' da Crianga, de 20 de Novembro de 1989 - dez. anos depois do "ano da rerianca» e trinta anos exactos, no dia e no mes (coincidência nä́o casual), depois da Decharaçäo dos Direitos da Crianca. Ratificada por Portugal em 21 de Selembro de 1990, a Convengão, mornente o seu ar\%. 3.", nomna cardinal no sistema desenhado, erige o «superior interesse da crianga» (expressäo também usada agora, na redaceño que the deu dei n." $31 / 2003$, de 22/8, no n." I do art. 1974." do $\mathrm{CC}$ ) como criterio das decisones que the digan respeito, comprometendo-se os Estados Partes a garantir, com todos os meios, a proteccáo e os cuidados necessários ao bean-estar da crianca".

assegurada its crianças c aos jovens, arts. $69.9^{\circ} \mathrm{e} 70.7$ Dentro dos direitos constitucionais de que são (também) titulares as crianças e jovens, merecem referência os arts. 24.", 25.", 43.", 63." (em particular o n." 3), 64.", 74." (especialmente als. a) e b) do n." 2).

"O que lambém se costuma exprimir falando da superação (a partir dos auos oitenta) do modelo de protecęão, focalizado na defesa do interesse do menor através da intervençä́o do Fstado, por um modelo de justiça, em que se privilegia simultaneamente a defesa da sociedarde e o respeito dos direitos, liberdades e garantias dos menores (com a correspondente intervenção judicial). Modelo este último que serve de «transtundo» à Convençäo dos Dircitos da Criança, à CRP e às alteraçoes que o direito dos menores, mais recentemente, experimentou entre nós.

iii Não tanto no sentido de um privilégio ou discriminaçăo positiva, mas sobretudo, como decorre do cue já se disse, tradurindo a «revalorização do menor na sua qualidade de pessoa» (RESCIGNO), quer dizes, «tratá-lo justamente, adequando a sua pessoa (nnonor de idade) os direitos e normas que como pessoa, nâo mais, the correspondem» (IRANCISCO RIVERO).

Todavia, deve sublinhar-se que de pouco ou nada serve conceder amplos diteitos e extensa proteção legal (lala-se até de uma «proliferação ou inlação de direitos») se as condiçōes de vida forem adversas às crianças e aos jovens. Nessa linha, mesmo nas sociedades desenvolvidas, em grande parte radicando na lógica c nos princípios increntes ao seu funcionamento, é fácil apercebermo-nos das precárias circunstancias (ou dos siutomas que as evidenciam) em que vivem as crianças e os jovens (doeumentadas nomoadamente nos relatófios iniciais e de aplicaçăo apresentados ao Comité dos 
Direitos da Criança pelos Fstados curopeus partes da Convençäo das Naçoes Unidas sobre os Direitos da Criança).

Pense-se, por exemplo e sem qualquer preocupaçăo de ordem: na năo erradicaçăo do trabalho infantil; na persistencia de uma taxa relativamente alta de moftalidade o morbosidade infantil; nas carências dos locais de habitaçăo e dos espaços lúdieos para crianças; na lalta de instiluçeos que delas se ocupem durante o período de trabalho dos pais; ma preparação insuficiente e falta de tempo destes para as tarefis educativas; na năo prescrvaçăo da «atmosfera familiar»; no abandono do lar por menores; na men+ dicidade infantil; na «concorenceia pouco salutar» entre jovens nas instituiçóes de en sino; no stress escolar gerado por uma carga excessiva de aulas (que nenhum sindicato aceitaria para os seus trabalhadores, como já alguém ironicamente observou) e por um excesso de expectativa e pressão; no abandono precoce da escola; na violência dentro desta; na criminalidade juvenil; na incidencia especial nos jovens do abuso de drogas; na frequência do gravidezes precoess; no abuso sexual de crianças e adolescentes; na violencia e maus tratos de que estes säo alvo, mesmo no interior da família; no desem.prego que os afecta; nos distúrbios psicológicos e suicídios entre jovens.

iv Dentro dos princípios fundamentais que subjazem à Convençăo cabe ainda mencionar o princípio de que todos os direitos se aplicam a lodas as crianças sem excepção e de que o Estado tem obrigaçăo de proteger a criança contra todas as formats de dis criminaçăo (art. 2."); o princípio do que todas as crianças têm direito incrente à vida, e de que o listado tem a obrigação de assegurar a sua sobrevivência o desenvolvimento (art. 6."); e o princípio de que a criança tem o direito de exprimis livremente a sta opinião sobre questóes que the digan respeito e de ver essa opinazo tomada em consideração de acordo com a sua maturidade (art. 12."). Indique-se também que a Convençăo conheceu, posteriormente, dois Protocolos Facultativos - un relativo ao envolvimento de crianças em conflitos amados, adoptado pela Assembleia Geral nas Naçoes Unidas em 25 de Maio de 2000 , e o outro relativo à venda de crianças, prostituiçăo e pornogralia infantis, adoptado pela Assembleia Geral nas Nações Unidas em 25 de Maio de 2000 - ambos ratificados por Portugal.

No plano do direito internacional e comunitário, directamente dirigido à protecęäo dos menores (a maior parte do qual vincula o Eslado portugues, vigorando, sendo aplicável ou até se integrando na ordem interna -... efr. ant. 8." al CRP), anotem-sc, cntre outros instrumentos intenacionats, por ordem cronológica:

No aumbito da ONU: a Declaraçäo sobre os Direitos da Criança (Gencba, 1924); a Convençăo relativa à cobrança de alimentos no estrangcio (Nova lorque, 1956); a Declaraçăo dos Direitos da Criança (1959); a Declaração sobre a proteçãa de mulheres e crianças em situação de emergência on de conflito armado (1974); o conjunto de regras múnimas das Naçöes Unidas relativas à administração da justiça para menores -.- «Regas de Beijing» ... (1985); a Declaração sobre os Princípios Sociais e Jurídicos aplicáveis à proteção e bemestar das crianças, com especial relerência à adopção c colocação familiat nos planos nacional e internacional (1986).

E ainda, a Declaração Universal dos Direitos do Homem (1948), o Pacto Internaciona! sobre os Direitos Civis e Políticos (1976), momente os seus arts. 23." e 24.", co pacto Internacional sobre os Direitos liconómicos, Sociais e Culturais (1976), momente o seu art. $10.0,11 . " 3$. 
Fa, especifcanente, no âmbito da Conferencia de Haia de Dircito Intemacional Privado: a Convençấo relativa à lei aplicável con matéria de prestaçăo de alimentos a menores (1956); a Convençăo relativa ao reconhecimento e execuçâo das decisöes em matéria de prestaçâ de alimentos a menores (1958): a Convençấo relativa à competencia das autoridades e a lei aplicável em matéria de proteção de menores (1961); a Convençio sobre a lei aplicável às obrigaços alimentares (1973); a Convençäo sobre o reconhecimento e execuçăo de decisóes relativas a obrigaçôes alimentares (1973); a Convenção sobre os aspectos civis do rapto internacional de crianças (1980); a Convençäo relativa à proteçäo das crianças e à cooperaçâo em matéria de adopção (1993); a Convenção relativa à jurisdição, à lei aplicável, ao reconhecimento, à execuçẩo è cooperação cm materia de responsabilidade parental e de medidas de protecęa dos tilbos (1996).

No âmbito do Conselho da Europa: a Convençấo Lunopeia em matória de adopção de crianças (1967); a Convençäo Furopeia sobre o estatuto juridico das crianças nascidas fora do casanento (1975); a Convenção turopeia sobre o rconhecinento e execuçăo das decisốes relativas à guarda de menores e solme o restabelecimento da guarda de menores (1980); a Convençäo buropeia sobre o exercicio dos direiros das crianças (1996), ainda nâo ratificada por Portugal; a Convençăo Europeia sobre a cibercriminalidade (2001), ainda näo ratificada por Portugal, especialmente no seu atf 9." 0 a Convençäo Furopeia sobre as relaçóes pessoais com crianças (2003), ainda näo ratidicada por Porlugal.

Importa também, claro, aludir neste contexto à Convençäo Europeia dos Direitos do Homem (1960) c aos seus Protocolos adicionais ... haja cm vista nomeadamente os arts. 3.", 5.", 6." 8." e 14." da Convenço o o at. 2." (o Protocolo 1." e à Carta Social liuropeia $(1961)$ - que contém várias referencias às crianças: ants. 7., 9.", 10.", 11."1, $160^{\circ}, 17.0 \mathrm{c} 19.0, \mathrm{n}, 0$.

Mencionem-se igualmento algumas reconendaçoes, directivas e resoluçoes da Assembleia Parlamentar: a Recomendaça 29 (1952), sobre a proteçäo da infancia em caso de guena; a Recomendaçấo 179 (1058), relativa às obrigaçöes alimentares face as crianças; à Recomendaçăo 194 (1959), relativa à lacionalidade das crianças filhos de apátridas; a Recomendaç̃o 196 (1959), relativa ao reconhecimento execuçăo das decisōes em materia de obrigaçoes alimentares face às crianças; a Recomendaçăo 1071 (1986), relativa ao bem-estar das crianças, assegurando-thes cuidados institucionais; a Recomendaço 1065 (1987), relativa ao trálico e outras formas de explonação das crianças; a Recomendação 107 I (1988), relativa à proteçăo da infância - acolhimento da infância e pequena infância; a Recomendaçăo 1074 (1988), relativa à política lamiliar, a Recomendaçäo 1093 (1989), relativa à educaçăo das crianças de migrados; a Recomendaçồ 1121 (1990), relativa aos dircitos das crianças; a Recomendaçăo 1149 (1994), relativa à educaçâo das crianças sobredoladas; a Recomendaçäo 1286 (1996), relativa a una estratégia curopcia pana as crianças; a Recomendação 1371 (1998), Maus-tratos infligidos às crianças; a Recomendação $1443(2000)$, sobre o respecito dos direitos da crança na adopçäo internacional; a Reconendaçăo 1460 (2000), Institução de $\mathrm{um}$ provedor curopeu para as crianças; a Recomendaçăo 1501 (2001), Responsabilidade dos pais e dos professores na educação das crianças; a Recomendação 1532 $(2001)$, Uma política social dinâmica em benelicio das crianças e adolescentes no meio urbano; a Recomondaçäo 1551 (2002), Construir no século XXI uma sociedade com 
e para as crianças: sequência da testratégia curopeia para as crianças (Recomendaçäo) 1286 (1996); a Recomendação 1601 (2003), Melhoramento do destino das crianças abandonadas em instituiçócs; a Recomendaçao $1606(2004)$, Proibir o castigo corporal das crianças na turopa; a Recomendação 1608 (2005), Direitos das crianças em instituiçäo: sequência da Recomendação 1601 (2003) da Assembleia Parlamentar; a Recomendação 1703 (2005), Profecçăo e assistencia das crianças separadas em busca de asilo.

E a Directiva n." $514(1996)$, para a promoçầo da causa das crianças; a Directiva n." $526(1906)$ sobre a exploração sexual das crianças; a Directiva n." 587 (2003), Melho ramento do destino das crianças abandonadas em instituição.

E a Resolução 1099 (1996), relativa à explotaçăo sexual das crianças; a Resolução $1099(1996)$, relativa à exploração sexual das crianças; a Resolução 1291 (2002), Rapto internacional de uma criança por un dos pais; a Resoluçăo 1307 (2002), lixplotação sexual das crianças: tolerância zero.

Do Comité de Ministros refiram.se as segumles recomendaçóes aos Estatlos Mem bros: Rec(79)3F, respeitante à inserção dos jovens no mundo do trabalho; Rec(79) 171 , respeitante à proteção das chanças contra maus tratos; $R e c(81)$. $F$, respeitante ao acothimento ceducaçäo da criança desde o nascimento até aos oito anos; Rec(82)2F, respeitante ao pagamento pelo Fstado de adiantamentos de alimentos devidos as crianças: Rec(83) 13t, sobre o papel da cseola secundátia na preparaçâo dos jovens para a vida: $\operatorname{Rec}(84) 4 \mathrm{~F}$, sobre as responsabilidades parentais; Rec(87)20F, sobre as reaçöes sociais à delinquência juvenil; $\operatorname{Rec}(90) 2 \mathrm{~F}$, sobre as medidas sociais respeitantes à violência no seio da família; Rec(91)1/ri, sobre a explonação sexual, a pornogralia, a prostituiçäo c sobre o trálico de crianças e jovens adultos; Rec(92)7/ relativa à contunicaçäo e cooperação no dominio da investigação sobre a juventude na Luropa; $\operatorname{Rec}(92) 11$ l, sobre a inserção social e profissional dos jovens; Rec(95) $16 \mathrm{~F}$, sobre os jovens e despotio; Rec(95) 181; sobre a mobilidade dos jovens; Rec(98)81; sobre a participaçäo dos jo vens na vida lamiliar e social; Rec(2001)16, sobre a proteção dos jovens contra a exploração sexual; Rec(2002)8 sobre o acolhimento diurno das crianças; Rec $(2003) 20$, respeitante aos novos modos de tratamento da delinquência juvenil e ao papel da justiça de menores; Rec(2003)6, para a methoria do acesso à educaçäo física e ao desporto das crianças e jovens em lodos os países europous; Rec(2003)8, sobre a promoģäo e reconhecimento da educaçăo näo formal dos jovens; Rec(2005)5, relativa aos direitos das crianças vivendo em instituiçäo.

No âmbito da Uniăo lauropcia: cortos artigos do Tratado de Roma, com aplicaçăo às criancas, v. g., att. 13.", art. 137.", art 143."; c a Carla dos Dircitos lundanentais, cm especial o seu ant 24."

O Partamento Europeu ocupou-se frequentemente da proteçao das crianças. Assim, por exemplo, na Resoluçäo de Julho de 1990, exortando os Estados membros a ratificarem com urgência a Convençăo das Naçōes Unidas sobre os Direitos da Criança e na Resoluçã̃o A 3-0)172/92, relativa a uma Carta liuropeia dos Direitos da Criança.

Quanto ao Conselho, importa destacar: o Regulamento (CE) n." 2201/2003, relativo à competencia, ao reconhecinento cà execução de decisôes em matéria patrimonial e cm matéria de responsabilidade parental e que revoga o regulamento (CL) n." 1347/2000) (este último tinha convertido $\mathrm{cm}$ direito commitário, no essencial, o conteúdo da Con- 
Aqui se insere o reconhecimento da autonomia do menor; que deverá ser salvaguardada e promovida em todos os asyectos da própria vida, a começar pelos «negócios pessoais», dentro e fora da família. Na medida da sua «aptidão de discernimento», segundo sua «maturidade», havera que ouvir - para utilizar a linguagem do Children Act ingles: wishes, feelings, needs-as requestas ou desejos, os sentimentos' e as necessidades do menor (cfr. nomeadamente art. 1878.", n." 2, onde se prescreve aos pais que tenham em conta a opiniäo dos filhos nos assuntos familiares inportantes e que thes recontre cam «antonomia na organizaçäo da própria vida», e ainda art. 1885.", n."2, parte final). E há-de ele desempenhar, assim, um papel activo, de co-envolvimento nas decisóes que o afectem, atendendo-se ao sea desacordo, fazendo-o participar ou até chamando-o a tomar, por si, tais deliberaçöes.

sto, aliás, justamente à luz dos principios e valores constitucionais, e com directa incidência na titularidade e exercicio dos próprios direitos fundamentais (recorde-se toda a problemática acerca da «Grundrechtsmïindigkeit»-palavra-chave: o «menor-cidadäo»).

Aflorados estes aspectos, que careceriam, é óbvio, de outro desenvolvinento, impöe-se assinalar (como repetirenos infra) a incindivel relaçäo cutre a autonomia e a capacidade (natural). Não tem, nomeadamente, sentido falar em antonomia, näo estando a pessoa em causa em condigöes de entender a relevancia dos seus actos, de reconhecer os seus interesses, valorá-los, e escolher os meios adequados à sua satisfaçäo. A antonomia baseia-se na «aptidão» para uma decisão livre e racional.

Eque, as mais das vezes, o Direito tenha de prescindir de uma averiguaçäo individual de tal «aptidäo de discernimento» ou «maturida-

vençăo de Bruxclas de 1996 , relativa à competêneia, ao reconhecinento è à execuçăo de decisōes em matéria matrimonial, que ainda năo entrata em vigor). Ea anda: a Açäo Comum 96/700/JAI, que estabelece um programa de incentivo c de intercâmbio destinado aos responsáveis pela acȩão contra o trático de seres humanos, e a Ação Comum 97/154/JAl: a Decisão quadro 2002/629/JAl relativa à luta contra o tráfico de seres humanos $(2000)$ e a Decisão quadro $2004 / 68 /$ IAI relativa à lula contra c exploração sexual das crianças e a pornografia inlantil.

Vem ainda a propósito, a mero título exemplificativo, apontar algumas sentenças do Tribunal tiuropeu dos Direitos do homem: caso Olsson contra Suécia $(27 / 11 / 1992)$; caso Hoffmann contra Áustria (23/06/1993); caso McMichael contra Reino Unido $(24 / 02 / 1995)$; caso Johansen contra Noruega $(07 / 08 / 1990)$; caso Buscemi contra lália $(16 / 09 / 1909)$; caso L.P. contra Itália (16/11/1999). 
de» (onde, em vez da «idade cronológica», estaria em causa a «idade mental»), ou seja, abdique de uma soluçäo casuistica, regendo-se preferencialmente por critérios" «normalizados» ou «tipicizados», é algo que não sofrerá contestą̧ão séria (vide infra).

Por ouro lado, deve recordar-se estar, neste contexto, em causa o direito e interesse fundamental dos pais (correspondendo também à plena realizaçäo da personalidade destes, como acentua Anrunis VAREAA), dentro da família e no ambito das suas funçöes igualmente garantidas pela lei fundamental, de chidarem dos filloss e os educarem (cfr. arts. 36.", n." 5, 67.", n." I, al. c), e 68.", n." I, da CRP - onde se fala da «insubstituível açäo» dos pais em relação aos filhos -, e art. 26.", n." 3, da Declaraşäo Universal dos Direitos do Homem) e o seu poder paternal, no contendo legalmente definido (art. 1878."do (C).

Daqui chega-se, se nüo a una antinomia, pelo menos a um eventual ditema (de una maneira geral sobre o antagonismo entre, por um lado, a proteçäo e, por outro, a liberdade dos «maiores incapazes», cfr. RAu. Gul(wari), Direito e Justiģa, vol. IX, 1995, tomo II, esp. pág. 132).

Em termos gerais, concordar-se-á com GrRNHuBbik quando este afirma: "Ziel des elterlichen Gewalt ist es, das Kind zur Selbstbestimmung zu befähigen. In ihrer Idealgestalt muss die Elterlicho Gewalt daher (particll oder total) enden, sobald das Kind zur Selbstbestim-

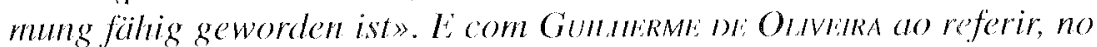
mesno sentido, que «a medida dos poderes de interventä́o dos pais reduz-se progressivamente até aos dezoito anos, com uma reduça rápida na fase final da relaçäo do poder paternal, motivada pelo desenvolvimento acelerado na fase de adolescência». Pode mesmo sustentar-se - como EsknaAk (e a sua sugestiva teoria da dynamic self determination) proclama - que a melhor forma de garantir, social e juridicanente, a proteçăo dos menores consiste em promover a sua antonomia como sujeitos.

E, congruentemente, manter-se-á que a finalidade primacial do poder paternal a que se encontratn sujeitos" os fillos menores consiste? en promover o desenvolvimento físico, intelectual e moral destes, com

"Expressöes - «poder»e «sujeitos»-.- de cuja justeza talvez se duvide, pot conoladas com um «modelo autoritário» na concepceão das responsabilidales dos pais, procuran do-se substituí-las, por exemplo, por «cuidado paternal» «eltentiche Sorge», no direito alemão; «ObSorge» (compreendendo «Pflege», «lisichung», «Vemögensverwal- 
vista à sua plena autonomia (cfr. arts. 1885." e 1878.", n." 2, segunda parte, do CC). Donde, conceber-se o direito fundamental de educaşäo e mamutengăo dos fillhos, em simultâneo, como um dever (um «direito-dever» ou, porventura, um «dever-direito», porquanto se trata de um officium mais do que um beneficium, sendo, de algum nodo, o interesse dos pais um elemento teleologicanente secundario e os seas poderes instrumcntais e limitados (cfr., aliás, o art. 36.", n." 5, da CRP, o arl. 1915.", to CC, e, de um modo mais gerat, art. 69." n." l, da CRP). lim suma, e como recorrentemente se afirma, o interesse do filho não deverá, em termos próprios, ser encarado como am limite ao poder dos pais de educarem e manterem os filhos, mas antes cono uma parte integrante ou imaneme dele, determinando o seu contéido.

Porém-e aqui queríamos chegar-, na prática (porventura näo no "ldealgestalt») sempre subsiste um campo de tensióo entre os «poderes» atribuídos aos pais (e susceptiveis, por vezes, de "realizaciono coerci$v a »$, dentro do «direito de correç̧äo» que àqueles se há-de reconhecer, mesmo inexistindo ho je qualquer preceito correspondente ao art. 1884. do Código Civil na sua versão originaria), a que corresponde o dever de ohediência imposto aos filhos (cfr. art. 1878.", n."2, primeira parte, $e$ art. $128 . "$ do (C), e a autonomia ou independência destes. E täo-pouco se vê ontra soluçäo viável ou preferivel senäo a de deixar, dentro de certos limites, a apreciaģäo do que convén ao ubem-estar» daqueles aos pais, que sä́ ou devem ser os mais bem colocados e os mais sensívess para desempenharem tal funcaion

Lung» c «gesctzliche Verfiretung»), como, desde 1989, se pode ler na cpígrafe do $\$ 144$ do Código Civil austráco. Também no direito ingless, o Children Act de 1989 fala agora, onde antes se aludia aos parental duties and rights, de parental responsability. "Fí que, alón de tudo, deve imperar um natual «retraimento» do Direilo, do Estadoe da própria Sociedade (sob pena de erodir o próprio «cence» das relaçóes familiares). Que se exprime, justamente, no «princípio da mínima intervençăo» ou no «princípio da subsidiaridade», latente nesta matéria no nosso direito positivo (cfr. arts. 36.", n." 5 , c 67.", n." I, al. c), da CRP, c ainda art. 18." da Convenção das Naçoes Unidas sobre os Direitos da Criança).

Depois, sucede que o «interesse do menor».. essa «notion magique» cono a designou CARBONNIER -, enquanto conceito indeterminado, escapa a uma definçăo c a uma «objectivaçăo» apriorística - «ricn de plus foyanł» ainda nas palavras do mosmo autor-, há de ser necessariamente apreciado em termos relativos, supồ a consideração da situação sub judice na sua complexidade e nas sua múltiplas «variáveis» (por vezes dificilmente accssíveis a «terceiros»), amiúde nāo detcmina univocamente a concreta 
Nolens volens, não há como se furtar a uma questäo nodal na perequaçäo da disciplina da menoridade: a procura do justo ponto de equilíbrio entre a proteçäo (e a correspondente responsabilidade dos pais) e a independência progressiva do menor rii . O alargamento das excepsóos à sua incapacidade, ou até pretender erigir como regra a capacidade, redunda, nalgamas circunstâncias, em detrimento da proteçao que the ¿́ assegurada (muitas vezes, pré-condiģäo da sta autonomia futura). Nesta ordem de ideias, conforme Lemounand mantém, "ll lintérêt de l'enfant est souvent davantage préservé par la incapacité qui le touche que par l'antorlomice qu'on veut lai accorder».

Sobre esta problemática, aue aqui näo podemos prosseguir, nos seas diversos aspectos (na óptica jaridica: constitucional, internacional e privatistica), consultar, entre muitas obras, Hanz Monm\%, Die (zivil) rechtliche Stellung der Minderjährigen und Heranwachsenden innerhalb und auBerhalb der Familic, Berlin, 1989; MARI Eañ QUADRATo, II Minore tra interessi e diritti, Bari, 1995; PAsquath Standonti, Capacita e minore età nella problemática della persona umana, 1976; PhinI Atston (Ed.), The Best Interests of the Child: Reconciling Culture and Human Rights, Oxford, 1994; PHIII' ALSTON, STEPHLN PARKLR, JOHN Sermour (Fd.), Children, Rights and the Law, Oxford, 1992 (em parti-

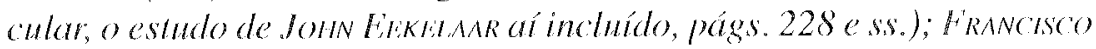
RIVIRo Hakninile, El interés del menor, Madrid, 2000. Sobre o poder

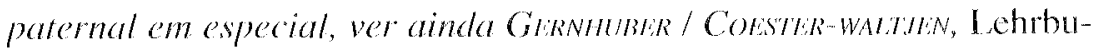
ch des Familienrechts, Mïnchen, 1994, págs. 855 e sss.; e, entre nós,

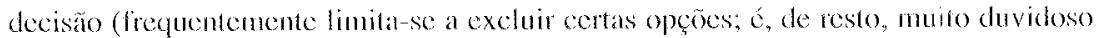
que o «best interest principle» deva ser interpretado cono um princípio de «maximisa. çăo») e, claro, nem sempre coincide com as opiniồes, sentimentos e desejos do próprio. Por úlimo, a concretizaço do «interesse do menor» está particularmente dependente de estereólipos o preconceitos valorativos. E diliculdades similares suscita a avaliaçăo da maturidade do mesmo para tomar decisoes de modo autónomo.

"Sugestiva é a construçăo de LISKEI AAR, mum artigo (The emengence of Children's Rights, Oxford Joumal of l cegal Studies, 1986 , págs. 170 c ss.) já com alguns anos, suscitado pelo caso «Gillick». o leading case (inglês) nesta matéria, sobre as consullas do planeancnto familiat e a prescriçăo de contaceptivos a menores, que teve enome repercussão legal e jurisprudencial. Aí, distingue o autor trếs lipos de interesse do menor: um basic interest, relativo a cuidados lísicos e afoctivos, um development interest. que se analisa no desenvolvimento das suas aptidöes, e un antonomy interest, variante do interesse anterior, que corresponde à possibilidade de agir sem o controle dos adultos, mas que estaria subordinado aos anteriores. 
MARIA CIARA SOTTOMAYOR, Exercício do poder paternal relativamente à pessoa do filho após o divórcio ou a separação de pessoas e bens, Porto, 2003 ; O poder paternal como cuidado parental e os direitos das criançass, in Cuidar da Justiça das Crianças e Jovens - A função dos Juízes Sociais, Coimbra 2003 , págs. 9 e ss.

Dito o anterior; e numa perspectiva de iure condendo, face ao direito civil português, pode aventar-se substituir o regime existente por ama «incapacidade parcial», rectius tuma incapacidade onde a forma de supriniento fosse a assistência (como a nossa lei já conhece para os inabilitados e conforme sucede na Alemanha, vide infra), pelo menos a partir de um certa idade, e porventura ressalvados alguns actos mais relevantes. Deveria também ponderar-se conceder à contraparte, que ignorava contratar com un menor, a possibilidade de pôr fim ao estado de incerteza sobre o desfecho do negócio (através da rejeiçäo deste ou, quando menos, através de uma interpellatio dirigida aos representantes legais"iii). Manter-se-iam as amplas «exceperoes à incapacidade» do menor constantes do art. 127." (porventura numa ordem e com uma redaçäo um pouco diferente: (fr., aliass, o anteprojecto de Gomis ba SuVA, BMI, 123, págs. 285 ess.), pontualmente alargadas para os maiores de dezasseis anos. Precipitado e inadequado seria, parece-nos, baixar a maioridade para os dezasseis anos.

Lim sentido parcialmente coincidente, para o direito francês, JWANJacQuis Lemouland, RTDC, 1997, págs. I e ss. Uma ponderaçä́ das vantagens do «sistema alemäo»p pode ver-se em HANS-GEoRG KNOTH, Die Geschäftsfähigkeit der Minderjähriger in geschichtlicher Entwicklung, Köln, especialmente págs. 363 e ss.; numa perspectiva diferente, $\mathrm{NI}_{-}$ COLA BUSC, Der Reifegrad Minderjähriger als MaBstab im Zivilrecht, München, 2001, págs. 153 ess.

Por outro lado, haverá que considerar a disciplina dos actos' pessoais. É reconhecido que as normas gerais sobre a incapacidade não se coadunam com o especial caráter de tais actos. Uma regulamentação

viii Como sucede no direito holandés, onde um negócio celebrado por um menor se considela, cm regra, anulável (Art. 3:32 ll Burgerlijk Werbock; note-se que a anulabilidade näo carece, necessartamente, de ser feita valer ope iudicis, bastando uma declaração dirigida à contraparte), no prazo de três anos a partir da maioridade ou do conhecimento que do negócio tenha tido o representante legal (Art. 3:52 I a BW), mas a contraparte pode assinalar um «prazo adequado», decorrido o qual fica precludido o direito de anulação (A At. 3:55 BW). 
adrede já existe para certos casos. A respeciva extensán e adcanarä́ devem porém ser repensadas, alargando pradentemente o espageo de autonomia assegurado.

Un ponto alterior, carecido de alleragäa, prende-se com a admi nistracano dos bens do incapaz, regida por regras «conservatísticas», algo timoratas, que desatendem à composiçäo modena normal do património, reflectindo lalvez uma desconfianga «de princípio» (e «alávi(as) face aos titulares dos poderes de administraçäo, menos justificada, 'laro, tratando se dos pais (pense-se, entre outros exemplos porventura mais relevames, nat probibicão, contida no att. $919 .{ }^{\circ},{ }^{\circ} 2$, de CC, de os pais realizarem qualquer doagäo em nome do filto). Em temos semelhanles, explicitamente, M. I. VAZTOML, J)I, vol XII, 1988, tomol, págs. 31.3 ess. E já, a propósito do suprimento da incapacidade dos interdilos, RAUI, GUICHARD, loc cit, esp.póg. 1.34.

\section{INTRODUÇ̃̃o}

Segundo o art. 123." do $\mathrm{CC}^{\prime}$, os menores, ou seja, as pessoas que ainda não completaram dezoito anos de idade ${ }^{2 / 3 / 4 / 5}$, carecem en princípio de capacidade para o exercício de direitos".

1 Salvo mençio con contrário, lodos os atigos cilados doravante pertencem ao Código Civil de 1960.

${ }^{2}$ Acerea da maioridade e da menoridade, fala-se por veres de um status on estado, por tradurirem aqueles conceitos ama condiçäo, näo precária nem descontínua, juridica mente relevante: perdurando por um período delimitado mas exienso, no caso da meno ridade; näo mais se extinguindo, uma vez adquirida, durante toda a vida, como sucede para a maioriade. O que, porém, carece de ser entendido de um modo hábil: no caso da menoridade, enquanto o menor tende ou caminha gradualnente para a capacidade; no caso da maioridade, por ter de se ressalvar a possibilidade de interdição on de inabilitaçăo. A ideia cte status acentua anda a imodificabilidade e a indisponibilidade pela vontade do próprio ou de tereciro (clre, quanto à capacidade juridica, ant. 69)." Lata-se, pois, de una matéria de ordem pública, dominada por normas inperativas).

3 Art. 122.". A contagem de lal pravo far se nos ternos das als. b) e c) do art. 279.", aplicável ex vi do ant. 296." (desprezando-se, portanto, o dia do nascimento).

O) ónus da prova da incapacidade (memoridade) impende sobre quem invoca tal circunstância como causa de invalidade, ou seja, os representantes do menor, este, uma ver alcangada a maioridade, ou os seus herdeiros. Istá, com efeito, em causa um facto impeditivo, cuja prova compete àquele contra quem a invocaçäo do direito é feita (ctr. ant. 342."). Aliás, a capacidade constitui a regta, o a incapacidadé ćncarata como excepçăo. Lim casos de non tiquel, afimar-se-á pois a capacidade. 
Cono, nomalmente, a idade de uma pessoa ó lácil de verificar, a prova incide aí sobre

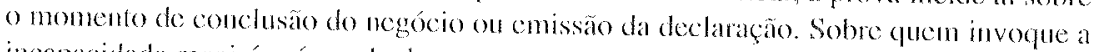
incapacidade recairá o ónes de demonstar que o negócio fol concluído quando acuela anda subsistia. Cfr, sobre isto, GOTTHRIED BAUMGÄRTLL, Hemdbuth der be. weislast in Privalrech, Köln, 1901, págs. 40 e ss.

${ }^{4} \mathrm{Na}$ redaçăo originária do art. 122,", a maioridade alingia..se aos vinfe e um anos. Na actual versäo, introdurida pela Reforma de 1977 (Dec. 1, ei n."496/77), a maioridade alcança se aos dezoito anos.

No que so seguiu a lição do direito comparado no plano europen (com excepçäo, inter alios, do direito austríaco, onde, até 2001 a partir daí, a maiotidade está fixada nos deroito anos - a capacidade se adquiria aos dexanove; junte-se ainda o direito suiço, que fixava o temino da menoridade nos vinte anos dezoito actualmente, por lei de 1994, yue cotrou con vigor em 1906). Acolhen-se, de resto, uma Resoluçáo do Comité de Ministros do Conselho da Eusopa (Resoluçäo (72) 29, teudo por base o Repor on the age of full legal caperity, de M. RYAN, onde se preconiza a fixaçöo da maioridade abaixo dos vinte e um anos, se possível nos dezoiro, ressalvados certos actos em domínios en que so entendesie conveniente a exigência de uma idade superior; recomendava is igualmente, sobretudo na hipótese de a maioridade näo ser fixada nos dezoito, que se reconhecesse capacidade aos menores para aclos proprios da vida corrente e noutros domínios sespecíficos). Ei procurou-se, por outro lado, harmonizar a legislaçăo civil com a lei elcitotal, que concedia já entäo, mas cleiçôes para Assembleia da República, capacidade eleitoral activa e passiva a quem tivesse mais de dezoito anos.

A ravão do fundo invocada era a do mais precoce e rápido processo de desenvolvimento e maturaço psíquicos c culturais dos jovens, fruto, cutre oulras causas, de uma esco-

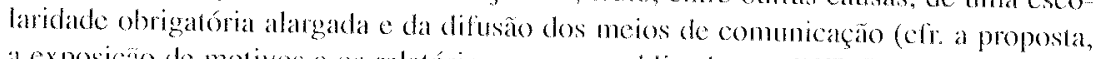
a exposiçáo de molivos e os relatórios ancexos, publicados no 1319DC, 1976, págs. 363 c ss. que mereed set companala com o keports of the Commitee on the Age of Ma jorty, London, 1967, sobre a mesma problemálica na Inglatera, mas cont dez anos de anteriondade, mais recentemente, 1982, a Eng/ish Law Commision preconizou o abaixamento da maioridade para os dezasscis anos). A lavor da antecipaçăo do ińcio da menoridade ainda se jumbáa a cada ver mas ampla proteçắo do consunidor e dos scus direiks: nalguns domínios de sobreposiçäo, tormou-se nenos premente a futela en função da juvenilidade de um dos contratentes.

A solução aroptada, (uL se impos sem contestaçăo, não deixou todavia de ser colocada em rela de juíro por AN'TUNLS VAREL A ao apontar subsistirem dúvidas se uma maior soma de conhecimentos corresponde, numa sociedade mais complexa, a um mator amadurecimento e a uma mais rápida independência ceonómica, e ao denunciar a falta de coerência entre a completa cessaçăo da autoridade paterna (cfi. art. 130.") e a manutencêo da obrigação de alimentos a cargo dos pais (cli. arts. 1879." c $1880 . "$ ). Céptico já se liuha nostrado em 1957, cm tomos muito sonehanks, CARBONNIER: «ll cst purement formel de proclamer la majorite du jeune homme, si, par le service militaire, l'allongement des études, ele, qui retardent l'entrée dans la vie, il continue a être économiquement dépendant». Outras objecẹôes, com $\mathrm{um}$ peso relativo, foram ainda colocadas, nomeadamente: a desproleceão dos inleresses dos jovens (podendo agora mais cedo delapidar o seu património); a mais fruste tutela concedida a terceiros a 
quem o menor cause um dano, os quais nào se poderiam prevalecer da responsabilidade in vigilando dos pais.

${ }_{5}^{5}$ De $4 \mathrm{~m}$ modo geral, com MAYtR-MAIY, FamRZ, 17 (1970), págs. 617 e ss., é possivel distinguit quatro questós e alternativas fundamentais com que so defronta qualquer ordem jurídica quanto à relevâneia da idade, à saber:

i) $\Lambda$ determinação das funçöes atriburdas ou preenchidas pela consideraçăo de «limites ctários».

ii) A opção, na apreciaçäo da maturidade e responsabilidade, entre um «procedimen. to individuatirante» ou um «procedimento objectivante» (mediante a construçäo de «limites etários», correspondentes a uma «média nomal de casos conhecidos ou ob servados», como o exprimia (CABRAI MONCADA), servindo este último a segurança e certera do tráfico jurílico. Ou seja, escolher entre uma apreciaçäo «en concrelo» ou «cm tomos abstraclos», alternativa com que depatamos já no direito clássico romano, onde a primeira via, realizada através de uma inspectio corporis, ea preconizada pela «Lscola» Sabiana, em oposiça aos Proculcianos. Hoje, aproximam se de lal soluçäo os dircitos ingles e suíço.

iii) A fixaçăo de un cstalão ctário conum a todos os mamos do dircito ou diferenciado consoante os dominios en causa.

A segunda possibilidade é abraçada por praticanente todas as ordens jurídicas logo no que respeita aos diferentes critérios de imputabilidade penal e civil. Mas rambém se constata noulros domúnios. Inclusive - como ainda refere MAYtR-MAIY, que vimos seguindo -- afigura se duvidoso que exista uma necessána conexão que imponha a assimilaçăo da capacidade eleitoral (activa) à capacidade negocial.

iv) A alternativa entre uma única cesuma principal, estabelecendo uma cortante dicoto mia cntre quen é capaz e quem nā́o o é, e um número elevado de «estádios ctários». O primeiro terno foi adoptado pela majoria das legislaçốes civis, conquanto na prátia o sistena se encontre mitigado pela introduçăo de váras derrogaçoes para certos domínios ou negócios. O segundo corresponde, por exemplo, ao modelo do direilo civil alcmão e. sobretudo, do dircito austríaco.

Detenhamo-nos, aliás, um pouco neste últino. Prevêen-se no direío civil austríaco três «patamares etáros» (principalmente no âmbito negocial; o Allgemenes bügerli ches Gesctzbuch … $\triangle B B B$ - contém ainda uma regulanentação relativamente detalhada quanto a «decisocs» afectando a esfera pessoal do menor, por veres comotendo-the a decisäo, outras veres exigindo o concurso da sua vontade, ou atendendo à capacidade de discenimento para ajuzar o concreto acto: cft., por exemplo, $\$ \$ 146$ c, $146 \mathrm{~d}, 147$ ABGB, $\$$ I FheC, $\left.\$ 50^{\circ}\right) \wedge B(\mathrm{BB}$ e $\$ 5$ RelKE(i).

O primciro patamar compreende as «crianças» com menos de sete anos, consideradas fotalmente incapares (《voll geschätsuntähig», \$865 Satz I ABGB), sendo os negócios por clas conclúdos nulos («absolut nichtig», cfr, $\$ 21$ 1, 151 1, $\$ 65$ Satz | ABGB, e $\$ \$ 2,102$ Ghe(i), mesmo se estritamente vantajosos (comparar Satz I e Satz 2 do 865 ABCBB). Note-se, ainda, que näo é possível a «ratilicaçăo» de lais negócios pelos representantes legais. Apenas se ressalvan, excepção que se estende a lodos os menores, os «alterstypischen Allagsgeschäfte»: negócios «próprios ou lípicos» da idade - permitindo, assim, uma progressivamente mais ampla participaçăo no trálico negocial --, respeilantes a assuntos de pouca importância e próprios da vida quotidiana - reduzindo, portanto, a exlensão de 
eventuats danos -, em que, alem disso, a prestaça do menor tenta sido integralmente cumprida (cfi \$ $1513 \mathrm{ABC}(\mathrm{B})$ ). Fm rigor, a lei austriaca estabelece que «com o cum primento das obrigaçoes da criança o negócio se forna retroactivamente eficaz». Porćm. lambém pequenas doações feiras a um menor sä́o consideradas eficazes.

Os menores com idade abaixo dos sete anos säo representados legalmente pelos pais (por regra bastara a intervençäo de um deles, mesmo perante a discordância do outro, cfi: \$ 1541 ; porém, ver $\$ 1542$ e 1543 e sobrefudo $\$ 144$ ) ou por aquela pessoa at cujo «cuidado ou guada» estejam entregues («Obsorgeberechtigte»; o conceito de «Obsorge» foi, conro já se disse, introdurido na lei austríaca con 1989).

O segundo grupo inclui os menores «näro cmancipatos», isto é, acpuckes que têm contre sete catorze anos. Aqui, os negócios que näo se mostrem, em termos juridicos. pura. mente vantajosos säo ineficazes (on «claudicantes» - «hinkende Rechtsgeschäfte») em relaça ao menor que os celebrou. Ou seja, o menor pode, por si só, «adquirir direitos» «bercchigen»- mas näo obrigat-we «verpllichten» (ch: \$15) I e \$80.5 Satz $2 \mathrm{c}$ Sitz 3 AliGB), lificazes seräo, tolavia, esses negocios quando os representantes os tenhan antorizado ou os ratifiquem (\$ 865 Sarz 2 АBGB) dentro do prazo razóivel assinalado pela contraparte ( $\$ 86.5$ Satz 3 ; a contraparte nä́o pode todavia simplesmente «revogar»o negócio).

O terceiro «degrau» abrange os menores com idade entre calowe e dezoito anos, ditos «menores cmancipados» («mïndige Minderjahriger, \$212 ABGB), e considerados aptos, con princípio, para governar allonomamente a sua pessóa e até os seus bens. Correlativamente, os pais ficam desoncmados de os sustentarem e de assumirem as suas despesas, em funça dos rendimentos de que eles passem a dispor ou da possibilidade que evidenciem de os obter (efr. \$140 3 AB BB; compare-se com o art 1879." do Código Civil Português). I: entende se, conquanto subsistam algumas reticências na doutrina, que a capacidade reconhecida ao menor (rectius, ao smenor emancipado») alasta o poder de represcentaçäo dos pais nos domínios correspondentes.

Assim, ao menor é atribuída (cfr. \$ 1512 ABGB) capacidate para dispor dos rendimentos que haja adquirido por virtude do scu trabalho, por exemplo, por virtude de uma rela(̧âo laboral, de un trabalho episódico duante as férias on de uma «actividade antónoma». Dematis, nos remos do \$ 1521 ABCiB, os contratos de sprestaçấo de serviços» nocessários para obter lais rendincentos (e, igualmente, os negócios ou actos unilaterais conexos on conformadores de semelhantes contatos: denúnciat, extinçäo por acordo, efc.) săo igualmente passíveis de serem celebrados de modo autónomo pelo próprio, conquanto com base em razoes ponderosas os representantes legais thes possam por termo. O menor é ainda live de dat o destino que contender às coisas ou ao dinheiro colocados à sua live disposiçäo, $1 .$, . a a mesada ou aos presentes que receba (cli. \$1512 ABGB). Fin todo o caso, ficam cxclúdos os negócios susceptiveis de lazerem perigar a satis. façäo das necessidades da vida do menor («Befriedigung seiner l, chensbedurfuisse», mormente, habilação, alimentaçăo, roupas; donde os negrócios para a satisfaçäo de tais necessidades prevaleceren sobre os demais). Fora das hipóteses referidas, será imprescind vel o consentimento do(s) representante(s), sob pena de inefićícia do negécio (que no entanto, pode ser unatificado», por cserito, pelo menor quando chega a maior - \$154 4 Saz, 2). Todavia, cabe referir a possibilidade de o menor ser autorizado a exercer lema actividade concrcial, podendo então dispor do rentimento obtido. 
Negócios de relevante alcance ou repereussióo ceonónica continuam, näo obstante, a requerer o consentimento dos pais.

Por outro lado, o $\triangle B C i B$ preve, no $\$ 154 b$, que o tribunal-oficiosamente ou a pedido da pessoa a quem esteja conctida a «guarda» - constate e dectare que determinada criança, por força de um notório afraso no seu desenvolvimento, de uma doença psíquica ou de uma deficiência mental, carece de capacidade (para discenir ou ajuizar) en determi nado assunto ou cículo de assuntos, decisão que perdurará até à maioridade ou à dáa ncla prevista, fendo incidência na capacidade jurídica do menor.

Antes de 200) l, estaval ainda contemplada (\$\$ 173,174 do ABGB) a possibilidade de «prorrogar», por decisäo judicial, geralmente a pedido dos pais, a menoridade ate aos vinte e um anos, se o sujeito demonstrasse grande imaturidade e alraso no seu desen volvimento. Inversancnte, era possivel requerer, detendo o próprio legitimidade para o cleito, uma «reduçăo» da menoridade, para que esta cessasse a partir dos de\%oito anos. E também já não se encontra hoje cm vigor (desde 2001: já antes linta sido revogado o $\$ 248$ АBCB, que continta norma semelhante) o $\$ 860$ ABCB que dispunha que quem livesse mais de dezoito anos e se fizesse passar por maiot ficava obrigado a indemnizat a contraparte, isenta de neghligencia grosseira, do dano (de confiança) causado. O pre ceito era, aliás, apodado por parte da doutrina de «burlesco». Se bem que haja quem lamente que o legistador näo tenha mantido, baixando a idade aí prevista para 16 on 17 anos, uma soluçä́) comparável, à qual corresponderia, mais do que a uma intençăo sancionatória, mana funçăo educativa preveniva.

Por último, mencione-se que, sobretudo malguns preceitos mais recentes do $A B C B B$, por

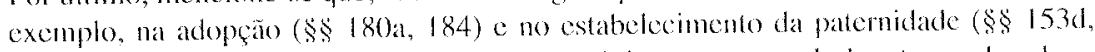
1630), se comprega a expressî́n «tigenberechtigung», a qual denota, malgrado a inexistencia de uma deliniçăo legal, a condição de quem ó maior e psiquicamente são, e, portanto, «voll geschältshahig».

Sobre o dircito austríco, cfi, por todos, PLIER BYDLINSKI, Bägerliches Recht, Allgemeiner Teil, Wien, 2004, págs. $32 \mathrm{ess}$; RUMMLI. (Hrsg.), Konmentar zum All

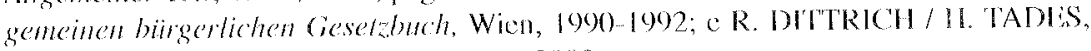
ABGB, MANZscher Taschenkommentar, 2002.

o Contudo, existe uma «categoria» de menores equiparados aos maiotes, aos quais se reconhece, en conlormidade, capacidade de exercício os cmancipados (efr. arts. 133." c 129."). Depois da Reforma de 1977, o casamento passou a sef a única causa de emancipaçăo (efr ant. 132."). Tendo fixado a maioridade aos dezoito anos. o legislador entendeu năo se justificar daí em diante a previs̆ăo de outras razöes de emancipação (anteriormente, aliás, so viáveis se o menor tivesse complefado de\%oito anos). O instituto ficou, por conseguinte, relegado a um «apêndice» do direito matrimonial, tradurindo o incontorúrvel reconhecimento da autonomia do menor casado e da necrssidade do poder prover às exigências da sua vida familiar («e mariage rend majeur» dispöe em estilo lapidar o art. 14,2, do Code Civil suiço). Porém, năo se omitirá indicar que, desse modo, se introduriu uma manilesta dispardade de tratamento entre os monores com mais de dezasscis anos que sejam casados e aqueles que näo o sejam.

Eun rigor, pela emancipaçăo o menor não acede à maioridade -.. entra no uspecial estado» de menor emancipado. Donde haver que reflectir sobre os cleitos da dissoluçäo ou invalidade do casamento quanto à «subsistencia» da capacidade. Todavia, face aos 
Preferivel seria falar de capacidade de agir ${ }^{7}$, porquanto não se trata apenas da susceptibilidade de exercitar (autonomamente) direitos, mas, de uma maneira mais geral, da possibilidade de, por acto próprio ou mediante um representante voluntário, produzir efeitos jurídicos, desenvolver uma actividade juridicamente relevante, mormente adquirir direitos e exercitá-los c assumir obrigaçốes c cumpri-las. No entanto, a expressão capacidade de exercício está consolidada entre nós.

dizeres peremplórios do art. 129.", «a incapacidade |. . | termina», a anulação, por causal distinta da falta de idade núbil, ou a dissoluçăo do casamenio parecem năo implicar a cessą̧ão da emancipação. Diferentemente, al lei austríaca, conquanto lambém equipare um monor casado a um maior, no que concerne à sua esfera pessoal, determina que tal apenas ocorte «enquanto o casamento dure» (ctr. \$175, in finc, ABGB).

Recorde-se que o menor com mais de dezasscis anos somente pode casar com a autori zaçâo dos pais ou do tulor, cuja lalta, quando năo suprida pelo conservador do registo civil, constitui um impedimento matrimonial impedicnte (cfi. al. a) do art. $1604 .^{\circ)}$. E tais menores săo incapaz para celebrar convençöes antenupciais, carrecendo para o efeito de autorizaço dos representantes legais, sob pena de anulabilidade, arguível e sanável nos termos do art. $17099^{\circ}$ (se o casamento se vem a verificat anda duante a menoridade, entäo, invocada a anulabilidade da convenção, considerar-se-á celcbrado sob regime da comunhão de adquiridos, de acordo com o ar1. 1717."). Não se ratarí, todavia, de uma verdadeira incapatcidade (de excrcicio; que não cstamos perante uma incapacidade de gozo resulta logo de ser ela suplível), por năo afectar a validade do casamento, sendo a Sancão apenas a prevista no ant 1649. Mais: o menor é sempre conancipado pelo casamento, adquirindo, nos demais aspectos, plena capacidade de exercício (cfr. art. 133."). Ėm geral, em hipóteses do género, usia-se falar de «negócios irregulares».

"handlungsfihigkeit, na terminologia alcmá; active legal captacity poder-se-á dizer em inglês. Mas aqui está em causa sobrefudo a capacidade no domínio negocial (Geschäfts fahligkeit; ransactional capacity). De fora fica a «capacidade delitual» (Verschulden fahigkeit. que os autores alemäes subsumem na Hondlungs/ihigkeit - ou defictual rapaciay). Vicle ainda infra.

Neste âmbito, impona também delimitar a noção de (in) capacidade de agir (negocial. mente) da de (i)legitimidade ou (de falta) do poder de disposição. Em ternos muío simplificados -- prescindindo de apurar se a categoria da legitinidade on do poder de disposizăo têm verdadeira unidade e valor autónomo -., mas que servem o nosso propósilo, pode afirmar-se, com MO'TA PINTO, que a capacidade é um modo de ser ou qualidade do sujeiro em si; a legitimidade expressa a relação da pessoa com determinado acto ou direito («a legitimidade supöe uma relaçăo entre o sujeito e o conteúdo do acto e, por isso, é antes uma posiçäio, um modo de ser pana com os outros»). Para maior desenvolvimento, acerea das «incapacidades conjugatis», da situaçäo do falido e da relação entre capacidade e legitimidade, cfr. MO'TA PINTO. Teoria Geral do Direito Civil, Coimbra 1980, págs. $239 \mathrm{css}$.

Advirla se, por fim, que a capacidade judiciária, isto é, a susceptibilidade de estar, por si, em juín, segundo os arts. 9." e 10.0 do Código do Processo Civil (CPC), segue as 
Distintas da noção de capacidade de exercício de direitos são, como se sabe, a de personalidade ou subjectividade e a de capacidade jurídica (de gozo). A primeira traduz a susecplibilidade abstracla para rece ber efeitos jurídicos, ser seu centro de imputação. A segunda define-se como a possibilidade de ser titular de direitos e obrigaçoes ou, mais genericamente, sujeito de quaisquer relaçöes jurídicas (cfr. art. 67.").

Como se vê, as duas noçöes tendencialmente coincidem. Porém, diz-se, a personalidade, como qualidade ou condição jurídica, é um quid simples, não admitindo limitações. Um ente tem ou năo tem personalidade, tertium non datur. E todas as pessoas singulares, desde que nascem até que morrem, a têm, como expressão do séu fundamental valor humano (efr. art. 66.", 11.01 ).

Diversamente, a capacidade jurídica (Rechtsfähigkeit) é um quantum, mensurável por graus, comportando restriçós. A de detcrminada pessoa pode ser mais ou menos ampla: isso mesmo exprimiria a ressalva contida no art. $67 .{ }^{\circ}$. «salvo disposição legal em contrário». Em todo o caso, as suas eventuais restriçoes assumem carácter excepcional - sendo a regra a capacidade (cfr. art. 67." do CC, e art. 26.", n." I, da CRP) -, tendo de estar circunscritas a actos específicos sob pena de, no limite, se negar a própria personalidade 8 .

Porém, as situações apontadas comummente como incapacidades de gozo (v. g., incapacidade de cassar, perlithar e lestar') deixam-se bem explicar como incapacidades de exercício não supríveis, já que se trata de actuações pessoalíssimas. Tanto mais que o valor dos actos praticados aí năo se revela uniforme, não constituindo, assim, uma razão de técnica jurídica para as diferenciar das incapacidades de exercício"."

regras da capacidade de exerécio de direitos. (já a «apapiclade» para depor como tes temunha apenas requer «apticlăo lísica e mental» para o efeito (cetr. art. 616.", n." 1, do CPC). No âmbito do processo do trabalbo lixa-se a capacidade judiciáta aetiva aos 16 anos (art. 2." n." I, do Código do l'rocesso do Trabalho).

${ }^{8}$ Como se afima repetidamente, o reconhecimento da capacidade jurídica (genal) a rodass as pessoas (físicas) é condiçäo primcina do princípio da igualdade.

9 Circenserevendo-nos à incapacidade on funçäo da idade, comecemos pela al. a) do ant. 1601.", que lixa a idade múbil nos dexasseis anos (quanto à celcbraçäo do matrimónio por menores com mais do que essa idade, vide supra), quer para o homen, quer para a mulher (anfes da Reforma de 1977, respectivanente, dezalsseis e a torze anos). Trata-se de um impedimento dirimente (absoluto) tornando o catsamento anulivel nos termos (a al. a) do art. 1631.". Ver ainda o at. 1632.", sobre a neces. sidade da sentença de anulaçao para que os cfeitos da anulabilidade se produram: 
A incapacidade geral de exercício, suprível nos termos do art. 124." $11 / 11: / 12 / 13$, corresponde, como consequência, a anulabilidade dos actos praticados pelos menores (cfr. art. 125.", n." I) 14/15/16/1/.

Oart. 1633.", n1." 1, al. a), acerea da validaçáo do casamento por condimaçán do casamento por parte do nubente, que o contraiu antes dos desasseis anos, após rer aringido a maioridade; e o art. 16.39.", quanto à legitimidade para intentar a acção de anulação. Refia-se igualmente que a lei equipara a incapacidade para celebrar convençöes an lenupciais à incapacidade matrimonial (art. 1708.", n." 1). Os menores com menos de dezasscis anos também näo possuom capacidade para perfilhar, segundo o art $1850 . "$ n." I (cft. ainda art. 1861." n." I e n." 2 , als. a), b), sobre a anulação da perfifluaçäo por incapacidade): tendo mais de dezasscis anos, o menor näo necessita - aclata o n."2 do art 1850." - de autorização dos pais para o cleiro. Por outro lado, dispồ o art. 2.189 .9 , n." I, serem os menores năo emancipados incapazes de testar, considerando-se nulo o testanchto feito pelo incapaz (art. $21900^{\circ}$ ). Por fim, note se que os menores näo emancipados (concuanto não privados, por regra, do poder paternal) estão de pleno dircito inibidos de representar o filho administrar os scus bens, segundo o n." 2 do art. 1913.". ${ }^{10}$ O que leva alguns autores a questionar se se justilica uma altónoma noçăo de capacidade jurídica (de gozo) delimitada negativamente sujeita a testriçocs. Cfr., cm sentido próximo, RESCIGNO, Capacità di agime, Novíssimo Dig. It., Il, Torino, 1981, pág. 862 c ANTONIO GORDHLIO, Capacidad, incapacidades, estabilidad de los comeratos, Madrid, 1986, págs. 28 ess.

Nesta ordem de ideias, registe se que na Common law se atribui decisiva importância à capacidade de agir on de exercicio. A capacidade juridica é definida em funçäo dacuela, năo constituindo propriamente un conceito aubonomo. Como assinala MÜ̈LLER - IREIENFELS, Die Vertretung beim Rechtsgeschäf, Tübingen, 1955, pags. $155 \mathrm{c}$ ss. a divergencia em relą̧a aos sistemas de ladiçăo romanística deve-se - mais do que ao pendor sistematizante destes últimos e à averão do direito anglo-saxónico a elucubraçöes conceptuais - ao distinto modo cncontrado pelas duas famílias de direitos para lidar com os dois probtemas subjacentes: o do reconhecimento das pessoas on entidades legais (colectivas) e o da proteção das pessoas singulares. Com eleito, e quanto a csta úlfima questão, os sistemas «continentais» (sobretudo depois da generalizada influência tudesca) procedem a uma dissociaçáro entre o litular dos direitos e aquele que os exercila, separando inicialnente a capacidade jurídica (de gozo) da capacidade de exercício, mats «reconciliando-as» pela instituiça da «representaçăo legal». Diferentemente, a Common l aw lança mão para resolver tais problemas da figua do «trust», que preserva na mesma pessoa a titularidade do direito e a possibilidade do seu cxercício, mas faz beneficiar dessa acividade a pessoa protegida.

"Ou seja, pelo poder patemal ou, subsidiariamente, pela tutela (note-se que os poderes do tutor são semelhantes aos dos pais, todavia menos extensos, cfr. arts. 1935." c ss.). Ao lado destes, pode ainda existir a administração de bens, nos casos previstos no art. 1922.". Fim situaçôes especificas, haverá lugar à intervençáo de representantes espectais do menor (cfr. por excmplo, arts. 1881, n." 2, 1891." -.. prevendo-se mesmo que o próprio menor requeira, na circunstância, ao tribunal a nomeaçào do curador especial; ver alinda 
att 1890.0 "n." 2, onde igualnente se recontece iniciativa processual ao menor " $1905 . "$

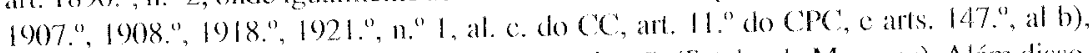
e 167." do Dec. 1 ei n."314/78, de 27/10, Organizaçäo Tutelar de Menores). Além disso,

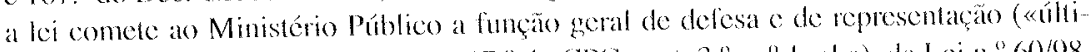
mà) dos incapares clir arts. 15." c 17." do (PC c art. 3." n." 1, at a), da l ce n." 60/98, de 27/8, Estatuto do Ministério Público (e ainda ant. 2.", n." I, do Dee.-Lei n."272/2001); e, especificamente, entre muitos casos, ants. 1893.", 11."3, 1915.", n."1,1918." 1920."do CC. Por lim, refirase a intervenção, no suprimento da incapacidade do menor, das pes. soas a cuja guarda, de facto, ele esteja confiado (que se poderão designat, com Carvas ho

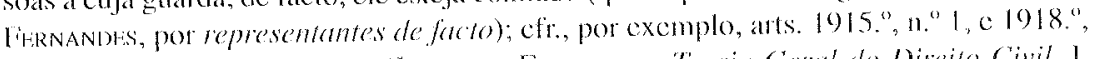
1893.", n." 3. Sobre isto, ver Carvalho Fiknandsis, Teoria Geral do Direito Civil, Lisboa, 1995, especialmente págs. 257 e ss.

A represemaçăo constitui, pois, no âmbito da menoridade a forma de suprimento da incapacidade (casos existem cm que os representantes legais carecem de auloriaçăo) judicial para a prática de determinados actos, efr., por exemplo, arts. 1889.", 1892.", 1938."). Como se sabe, o representante legal age em nome e no interesse do incapaz, substituindo-o, actuando em vez dele (de modo diferente, o assistente fimila se a actuar ao lado do incapaz, consentindo ou impedindo que cle actue).

Vate ainda a pena assinalar a eventualidade de alguém agio como gestor de negócios do menor (quer actuando em nome próprio, quer em nome deste, quer na falsa qualidade de representante legal do menor). Sobre estas últimas hipólese, ver o que dissemos em RDLS, 1995, ano XXXVII, pág. 6.

11 porém, fuid iuris se o representante legal autorizal o incapaz a praticar determinado acto para o gual este carece de capacidade, contrecendo, ou mesmo ignorando, a contraparte tal consentimento? Na doutrina italiana, recorre-se à construção cngenhosa, mas algo artificial e não isenta de objeçōes (BYDI INSKI designa-a, para os direitos austríaco e alemão, «juristische Wirblattkonstruktion»), de considerar o menor núncio ou representante (recorde-se que $\mathrm{t}$ m menor pode ser procurador, de acordo com o art. 263." do CC, onde se requer apenas a «eapacidade de entender e querer exigida pela na. tureza do negócio»; e a um núncio nem isso se exigirá), (los seus representantes legais. Um outro problema que pode surgit, neste contexto, é o de saber se, em certos casos, não será de atendet ao «estado subjectivo» (designadanente ao conhecimento de bactos que possam intluir nos eleitos do negócio) do menor em cujo nome o negócio b realizado. Questäo tanto mais pereuciente quanto o art. 259.", que trata da questão (da posiçấo do representado e do representante, a propósito do negócio representalivo, quanto à lalta ou vícios da vontade e estados subjectivos relevantes) de uma mancira geral, năo se refere, olhando à sua integlação sistemática (Divisão I -- Princípios gerais - da Subsecção VI ... Representaçäo), apenas à representaçăo voluntária. Costuma ligurar-se o seguinte «caso de escola»: um rapar de 16 anos induz o seu representante legal a adquirir em seu proveito objectos que só cle sabe terem sido furtados. Na ponderaçáa da lei, como se dirá a seguir, o interesse da proteção do menor sobreleva o interesse da protecçăo da contraparte, o que depố a favor da inconsidemą̧o do conhecimento daquele. A soluçấo năo é, no enfanto, segura. O problema «inverso» pode também colocar-se: prejudica o menor, que actua por si, o conlecimento dos seus representantes? Sobre esta questäo, ver, por todos, ALBRRECHT TINTEL NO'T, 17, 1987, págs. 795 c ss. 
12 Os ats 122." ess. (referentes à menoridade) possuem, na realidade, um carácter mui to menos genérico do que aquele que a sua inserção sistemática integlados no l ivo l do Código Civil, na Parte Geral pode layer supor. As derogaçoss on desvios, nos ounos Lives, săo numcrosos. Llaja om vista apenas o disposto quanto a capacidade para receber e realizar o cumprimento (art. 764."), para adquirir a posse (cft. 1266."),

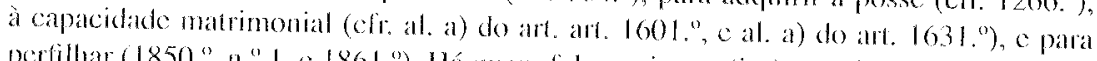
pertilhar (1850." n." I, c $1861 . ")$. llá quem fale aqui em «(in-) capacidades espectais». 13 Näo é assim na Common law, como já se deu a entender. No direío ingless nomeadancnte, os pais năo detên tum poder de representaçăo genérico no que concerne aos filhos menores. Têm, isso sim (para além do «poder relativo à pessoa do fillow, de que agora náo cumonos), a posiçáa de um «guardian», com poder de administração dos móveis que integram o património daqueles. No denais, em domínios espećficos, os interesses do menor são prosseguides por pessoas para o efeito munidas de especiais poderes de representaçio. Além disso, se, por exemplo, o menor herda determinado parrimónio a tirularidade deste pertence, até à sua maioridade, a um «lruste», podendoo menor apenas dispor dos rendimentos. Ao dircito ingles a tambén, e correlativanente, estranho o conccito de uma incapacidade negocial geral. En bodo o caso - em vista da sua proteção, mas infentando subsidiatianente proteger tereciros que de boa ro contratem con menores -, a capacidade destes está em certos grupos de casos limilada, casos esses deteminados em lunçăo da capacidade natural, mas sobretudo segundo o contédo, al haturesa e o aleance do negocio.

Não obsiante, por comodidade de exposição, tomenos como ponto de partida a proposição de que os contratos celebrados pelo menor säo «voidable», só vinculando a contraparts: (conquanto a cventual acçao de cumprimento incentada pelo menor - que atqui deve ser representado por un adullo, o «next fricond» ou, inicialmente, «prochan amys, năto necessariamente os pais pressuponha a realizaçăo da contraprestaçón). Pode, porén, oconcr a sta «ratilicaçao» peto menor quando atinja a maioridade (uma «ratificaçăı» pelos paisé desconhecida do direilo inglés, assim como a «liquidaçăo» do negócio «inválido» não supoòe a vontade destes).

Inclusive naso sucedendo a ratificaça con princípio, o menor hate pode repetir o que teuha prestado. O que, seguramente, como a generalidade dos aulores adverte, representa uma lacuna na proteçäo que a lei the quer asseguma (em contrapartida, ele ramente deparará, na generalidades dos negocios, com a recusa da contrapate com celebrá los, sobretudo so o cumprimento for imedialo co paganento em dinhero). Já as prestaçoes recebidas pelo menor, que năo hajam sido pagas, nä̀ tendo percecido ou sido consumidas, deverâo ser restirúdas (ou aquilo que com clas cle tenha obtido) quandoo jui\% o entenda «just and equitable» (Minors' Contract Act 1987, See. 3).

Quatro lipos de contratos (os chamados «eontinumg contracts»), conquanto «voi. dables», vinculam ambas as partes (em casos excepcionais un «confinuing contract» pode constivil um contrato sobre «ncesssaries»e, portanto, cstar submetido à regtas próprias destes, vide infro). Thata se daquetes contratos pelos quais o menor adquire direitos com carácter duradouro, «interest of permanent nature», a saber: contratos de aquisiçáo, arendanento ou «locaçăo» de «innóveis» («conflacts fo loasc or purchase land»); a aquisiça de quotas ou açoós de uma sociedade («shatres in company»); contratos de socicdade («partnerships»); c convençöes antenupciais («marriage seltements»). 
O menor possui, porem, a laculdade de os «anular» (sem necessidade de ana acçä) judicial, nem cle fundamentaçăo) durante a menoridade e, num «reasonable» prazo, depois da maioridade. limprincípio, a anulaçãotem meroscleitos ex nume, prese vando se as prestaçoes realizadas ou devidas até esse momento (com exeepăa dos muto tatos casos en que o menor näo tenha recobido qualquer contraprestaçăo, "lotal failure of consideration» - aqui não no sentido de ausência de promessa de contraprestaçăo, mas de falta de realizaçăo da contraprestaçăo--, onde poderá repedir o que haja prestado). Deve notar-se, com a generalidade da doutrina inglesa, que náo se atina com uma ver dadeira c substancial tarão, para além de uma tradição de vários séculos, que justifique o tratamento especifico a que cstấo submetidos os «continuing contracts».

Já todos os contratos que tenham por objecto os «necessarics»... «all goods suitable to the condition of life of the minor of other person eoncented and to his actual requitements at the time of the sale of deliverys (Sale of Goods Act 1979, Sec. 3, 3) -.. villculam a contraparte e omenor. Resultam da definiça da lei, e da prática jurisprudencial, dois critérios fundamentais para saber se o objecto do contrato deve ser encarado como «necessary»: o «estatuto social» do menor e a necessidade do bem vendido (ou alugado), atendendo àqueles do mesmo género de que o menor actuahmente jí disponha (curiosanente, o ónus da prova sobre a neessidade para o menor dos bens recai sobre o vendedor daí já ter sido sugerida a substimiçăo de una aprecinçăo individual dos «necessaries» por uma apreciaçăo objectiva).

A «rule of necessaries» ć, aliás, aplicada de uma maneina assaz flexivel e latitudinária pe los tribunais (o que, de resto, decorre da circunstância a que já se aludiu dos pais ou tutores não deterem un poder de representaçăo genal que thes permita actuar vinculando o menor). Eim fodo o caso, o bem há de ter sido realmente entregue; e o menor fica obrigado (com fonte num «quasi contract» que apenas surge com comprimento pela outra parte e o consequente entquecimento) a pagar un preço «aroável», que, por vezes, poderá não coincidir com o acordado (Sec. 3, 2, Sale of (roods Act).

Para atém da aquisigâa (ou aluguer) de bens, os «necessaries» abrangem (ou, pelo menos, a sua doutrina aplica se-lhes por analogia) os contratos de prestąa a de servicos e. g., educativos, médicos ou legais - necessários ( nnecessary services»)

Por outro lato, também o empréstimo on concessäo de crédito para al aquisiçăo dos "necessaries» vincula o menor (na medida en que o dinheiro recebido tenha sido electivamente utilizado com esse fim).

Por último, säo ainda considerados válidos os «employment contracts» (c contratos altálogos) que se mostrem globalmente (e năo em todos os ponlos, como acontece pala os «necessaries») benéficos (e näo scjan intsuals; afastados ficam ainda os contratos relacionados con uma actividade concreial do menor) para o nenor («benefical contacts of services»), mostmo que o contrato represente o modo de vida ou subsistência deste: contrato con um clube de futcbol, sobre os dircitos de autor, ete. lmprescindivel será, em todo o caso, que o negócio não combarie nomas imperativas por exemplo, disposiçoes legais sobre a idade mínima para exereer deteminada actividade. Fstá ayui, claro, subjacente a ideia de que, desse modo, o menot se irá preparando para se torna verdadedamente independente e vir a obter, por si, os meios de subsistência necessários. Digno de nota é que o menor não pode, ele próprio, pôr fim a tais contratos (a menos que isso se mostre estritamente vantajoso para elo). 
lim jeifo de conclusäo, vale a pena acenuar que, cono se verifica pelo exposto, o di reilo inglês encara o problema da proteção do menor essenciatmente da perspectiva (á sua preservação de desvantagens económicas e nấo, como a maioria dos sistemas continentais, do ponto de vista da formação da vontade negocial.

Cir, sobre o dircito ingles, cntre muitos, JOIIN BURKE o PLTER AI I SOP (edit), Chitty on Contreys, 29:" ed., KOIFMAN/MACDONALD, The law of Combact, 4." ed., 2001 págs. 205 e ss., VP. BIRKS (cdit) Englishl Pribale Law, 2000), págs. 96 e ss. NICOL A

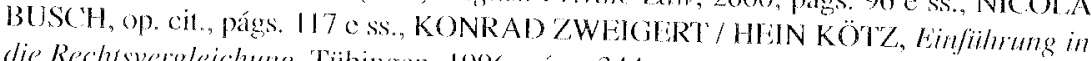
die Rechtsvergleichung, Tuibingen, 1006, págs. $344 \mathrm{css}$.

14 O que năo exclui que o acto do menor de muito tena idade, a quem falte um minimum de capacidade de entender ou querer (grosso modo, o «mineur dépourvu de diseerneinenls da dourrina e jurisprudência francesas), se possa configurar cono uma situaçăo a integrar no att. 246." (falta de consciência da declaraçäo), não produzindo, portanto, qualquer efeito. Cfr. CASTRO MLNDES, Teoria Geral, vol. 1, pág. 402 e K. LARLNZ / M. WOI I, Algemeiner Teil des BGB, München, 1997, pág. 138.

Por seu turno, a aplicaçäo do all. 257." (incapacidade acidental) a um negócio conclúdo por um menor carce, por regra, de importância prática: o acto seria anda anulavel o dentro de requisitos mais «apertados». Mas, recobrara o seu interesse no âmbito das excepçoes à incapacidade. Ima oura hipótese pensável conquanto «escolástical» (até por stpor um «dolo pretérito») - será a de farce intervir a incapacidade acidental se estiver precludida a anulação do negócio nos temos do art. $126 . "$.

Cabe anda referir que o negócio celebrado pelo menor pode ser amulável (ou modificável, o que por vezes representarí una soluçáo mais adequada) por configurar um negócio usurário (cli. arts. $282.0283 .{ }^{\circ}$ ), ponto éque a contraparle tenha obtido um benefício excessivo ou injustificado, utilizando em seu proveito - serăo as hipóceses aqui mais importantes - a inexperiência, fraqueza de carácter ou ligeireza do menot. Aliás - este será um ponto năo despiciendo de lege fersuda --, tal possibilidade torna menos instante uma proteção específica para o menor, e pensável, portanto, o alargamento das excepçoes à sua incapacidade. Frisc-se todavia que se exigc, no negócio usmário, un «elemento subjectivo» que se traduz na intençäo da contraparte de explorar o «estado de necessidade» (mas, depois da a teração introduzida pelo Dec. I Lei n." 262/83, não se recquer a obtenção de um beneficio manifeshanente excessivo, tomando-se mais lácil a anulaçăo, já praticamente sinónimos săo a anterior expressắo «aproveitando conscientemente»e a actual «explorando»). lei uma regulamentaçăo adrode pensada, como sucede por exemplo para a aquisiçấo da posse, efr. art. 1266.", ver ainda art. 1289."), teremos como criterio geral, sem dispensar uma análise diferenciada, que o regime do art. 125." thes sera aplicável na medida em que as respectivas consequências jurídicas se conectem em primeina linha com a vonlade do seu autor (o que será especialmente o caso nos actos quase-negociais). A analogia da sitnação, de que fala o art. 295.", deve apurar-se, antes de mais, na perspectiva da finalidade de proteção do próprio incapar que subjaz à regulamentação da menori-dade. Cfr., 1\% cx., Minchener Kommenktr, München, 1984, vor 104 , RdN 71.

16 Uma declaraçấo negocial recepticia (näo conducente à conclusão de um contrato, por exemplo, uma declaração de resoluçáo ou de despedimento) dirigida e recebida por um menor năo se fornará clicaz encuanto não chegar ao poter ou conhecimento 
(chr. art. 224.") dos seus representantes legais. Näo pode manifestamente ser de outro modo, mesmo inexistindo entre nós uma disposiçäo como a do 131 do Bargerliches Gesetzheh (BGB, doravante). Abrir-se-á uma excepçäo para aquelas declataçós que importem para o incapay apenas uma vantagem, por exemplo, renúncia de um dircito pot terceiro a lavot do menor (se se tratar de um negócio receptício). Soluçio que so pode talve\% ampara no regime (tecnicamente «espúrio») estabelecido para as doaçoes puras e simples feitas a incapazes, onde se prescinde da accitaçăo (efr. art. 951.", 11."2). 17 Vale a pena contrapor à nossa regulamentaçäo legal, nos aspectos já aludidos e noutros de que anda se tratarí, as soluçoses adoptadas ma Alemanha. Aí, começa-se por estabelecer a «incapacidade negocial» (Geschäfsumfähigkeit) dos menores com menos de sete anos (efi: \$ 104 I BGiB), que conduz à nulidade dos negócios por eles celchardos (\$ 105 1). A sua incapacidade é suprida pelo poder de representação legal concedido, em regra aos pais (\$\$ 16261 e 1629 13GB). Isualmente incapaz considera o $\$ 10411$ quem (maior ou menor) se encontre num cstado duradouro de mórbida penturbaçăo da acividade mental, que excha a «live deteminaçăo da vontade». Objecto de controvérsia é se, hace à lei, é concebível um «estado de parcial incapacidade», confinada esta a um cetto círento de negócios ou assintos, náo se reve lando o sujeito incapar para os demais actos.

A disciplina do \$ 105 I -- tem interesse referi-lo - ao considerar semelhantes negócios indiscriminadamente nulos, foi objecto de reservas logo aquando da feitura do BGB. Ii, recentemente, a discussä́o à sua volla reacendeu-sc. CANARIS, J7, 1987, pág. 993 e ss. (ver ainda a «ćplica» de RAMM e WIESER, e a «tréplica» de CANARIS, I7, 1988, págs. 493 e ss.) trouxe de novo a questão para primeiro plano, alo exprinio a opiniăo de que os 105 BGB (a crítica do autor dirige-se ainda a onfos preceitos do BGiB, alguns entretanto altefados) - na «(ramática restriçăo» que contém da «liberdade genal de actuação», do «direito geral de personalidade», da «aulonomia privada» do incapa - representania uma violação da proibição consitucional de excesso, no domínio do di reito das incapacidades. Concretamente, no estatuir-se a mulidade (insanável) dos actos do incapar, violar-se-ia o art. 2 I GG. Assim. CANARIS vem preconizar a substiluiç̃o de tăo desproporcionada e inadequada sançäo -.. malpropicia ao interesse do incapaz, ao permilir tambén à outra parte prevalecer-se da invalidade - pela aplicação analógica dos 107 ess. BGB (vide infia nesta nota).

Entretanto, ocorre salientar, una alteraço legislativa, de $23 / 07 / 2002$ (cfi., porén já antes, o \$1903 $112 \mathrm{BCB}$ ), veio adir o \$ 105 a BCB (nuito criticamente, quanto à inseręâ sistemática è redaceão que veio a prevalocer, pronunciou se logo o Bundesrat, BT-Drs. 14/9531). Lste preceito ficciona como elicanes ex nanc, aquando da realizaçäo das presta çóes, os contratos (näo os negócios unilaterais, excepto porventura os «negócios reais», mormente a «Übereignung») celebrados por maiores (também abrangidos no ș 105 , como já se releriu) incapazes, deside que importem apenas um dispêndio de peyuena importâneia e não representem um perigo relevante para a sua pessoa ou património (o gue, de resto năo é muito fácil de conceber). O negócio considera-se clicar, porén, apenas no que respeita às prestaçoes realizadas, excluindo-se a sua repetiçăo (scgundo o modelo anğo -americano para os neecesseries), mas já näo quanto, por exemplo, ao direitos (que assistam à contraparte em virtude do cumprimento defeituoso do incapaz. De fora ficaran todavia, pelo menos segundo a letra da lei, o negócios celchados por incapares monores. 
Quanto aos menores com idade compreendida entre sete e dezoito anos, possuem cles, segundo a lei alema ( $\$ \$ 106$ o 2 BGB), «capacidade negocial limitada» (desde que näo intervenha o $\$ 104 \mathrm{II}$, vide supro; c nao terão, por regra, capacidade processual, cli. \$2 ZPO). Também lace a cstes, detêm os pais (amplos) poderes de representaçâ legal (\$\$1620 1 \% 1629 BCB). Os contratos que tais monores concluam, por si, săo entäo inclicazes face a cles («schwebend unwirksanc Geschälte»; ressalve-se a eventual mulidade do negócio, segundo o \$105 11 , se realizado num estado de «alta de consciência ou ocasional perturbaçấo da actividade mental»). A menos que tenha havido uma «alutoriaçâ)», ou scja, um «conscntimento prévio» («Einwilligung», cfr. \$ 107) dos representantes legais. Ou ocorra a sua «arificaçäo», on seja, um «conscn fimento ulterior» («Genchmigung», \$108 1) por aqueles ou pelo menor (puc entretanto temba acedido à maioridade (\$ 108 III). Note-se que a ratificaçăo, de um modo geral, poste ser dectarada tanto face ao menor como face à contrapante (\$ 182 1), e nấo carece de forma $(\$ 1821)$.

Só cue, até a «ratificaçăo» ocorrer, a contraparte dispóc da possibilidade de «rejcitar» o contrato, através de uma declamaço dirigida aos representantes ou mesmo alo menor, se desconhecia efecrivamente a condiçäo deste ou se confiou por indicaçào dele na existencia de una autorizaço (\$109). Pode anda a contraparte, cm qualquer caso, «interpelar» os representantes a tim de estes se prontunciarem dentro do prazo (legal) de duas semanas (a ratilicaçăo on a sua recusa deve aqui ser dirigida à contraparte), decorrido o qual, o silêncio significara a negação de ratilicaça (\$108 11 ; há quem pondere a aplicaçấo analógica do nesmo regine as hipóteses em que os pais autorizaram previamente o negócio, mas náo comunicaram a autoriaçăo à contraparte). Não se adinite uma «ratificaçăo parcial» ou «correç̧ăo» do negócio, al qual pode, fodavia, constituir uma nova proposta contratual.

lá um negócio unilateral só cosusceptível de ser realizado pelo menor (tratando-se de um negócio unilateral lace ao menor aplica-se o \$ 131 BGB) com o consentimento prévio dos representantes legais (cfr. \$111). I a contraparte lem a faculdade de «repudiar» o negócio receptício, devendo-o fazer acto contínuo, se não the for exibido documento escrito donde conste tal atutorizaçâo (nem esta the teuha sido comunicada pelo representante). Exceptuam -se aquelas situaços em que a outra parte anui à realizaçăo do negócio apesal da ausencia de autorizaçăo.

Dito isto, importa assiualar que, na dúvida, a «autorizaçăo» concedida pelos representantes para a celebração do negócio pelo menor é entendida como um «assentimento» especílico para un concreto negócio, numa interpretaçöo restritiva ditada pela ratio da disciplina legal dirigida à proteçẫo do incapaz. Admite se, todavia, tma «atutorização geral», para determinado círculo de negócios, a qual contudo näo deverá servir para frustrar a finalidade da lei.

Por outro lato, no \$107 ressalvam-se-considera-os, portanto, cficares, independentementedoconsentimento dos representantes a apucles negócios que apenas acarrelem para O menor una «vantagem jurídica». Para o efeito, atender-se á à tolalidade dos efeitos jurídicos, e năo, propriamente, às consequências conónicas do negócio. A favor de um ral critério csuriamente juridico - an invés, por exemplo, do adoptado no direito francês na «rescision pour lésion»-., depoe sobretudo a facilidade de aclaraçäo da siluaçáo 
pelos intervenientes, ou seja, pela contrapane e pelos representantes legais. Discule-se, porém, se os cfeilos jurídicos mediatos por exemplo, impostos que recaian sobre o inóvel doado ao menor - - săo também de levar em contá.

Nestes termos, wn contrato bilateral nunca tepresentará um negócio «puranente van. tajoso» (há necessariamente obrigaçöes para o menor; mesmo a mera eventualidade de tais obrigaģoes, cono sucede nos negócios bilaterais imperfeitos ou acidental mente bilaterats, exclui (ue o menot os possa celebrar livremente). Mas, inclusive un contrato unilateral (em que só a outra parte se obrigue) é passível de se revelat juridicamente desvantajoso, dada a possibilidade de naseerem econ base lla lei», no

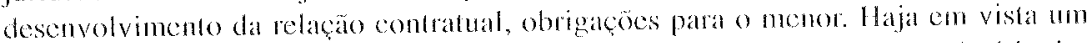
mandato gaatuito, onde poderäo surgir as obrigaçese de rembolsar o mandatário das despesas feilas e de indemuizá-1o do prejurzo eventualmente sofrido por culpa do mandante. Objecto de controvérsia é se o cumprimento electuado ao menor se tem por elicaz quando năo implique para ele uma desvantagem juridiea (pesará aqui a concepçáo que se lenhat sobre a natureza do cumprimento).

Numa extensio teleológica do precoito, pretende ainda parte da doutrina abarcar no $\$ 107$ (podendo, pontanto, o menor actuar sem autorizaçäo dos pais) os «negócios noutrais», isto é, aqueles que năo impliquem nem uma vantagem nem uma desvantagem, da perspectiva do incapaz (che, de resto, $\$ 165,1791112$ BGB e note se que. nesta perspectiva, o reconhecimento da capacidade de lestat, no $\$ 22291$, aos maiores de 16 anos, representatá, näo tuna «atenuaçăo», mas mua «agravação» do regime do $\$ 107)$.

Preservan-se igualmente, segundo o disposto no \$110 BCiB, os negócios (vantajosos ou desvantajosos) conchúdos pelo menor e por cle incgralmente cumpridos com meios que os representantes legais, ou tereciro com a consentimento daqueles, the confiaram para esse lim ou para sua live disposiço. A «liberdade» de disposiçăo de tais meios é, no entanto, entendida de manciras distintas: ona de modo absoluto, ora tendo em atençäo a vontade presumível dos representantes, ora apelando a uma vontade «objectivada», que excluiria a realizaçăo de certos negócios.

O \$ 110 ć apelicado «Taschengeldparagraph» (que podemos fadurir muito livenente por «artigo do dimbero de bolso ou pata despesas míndas»). Nele, de resilo, năo se inclui apenas a «nesada» on equivalente, mas fodos os rendimentos postos pelos represcontantes à disposiçä́ do menor, por exemplo, uma «botsa de esturio» por ele ganha ou a remuncraçăo de um labalho que haja prestado duante as ferias (mas ná, por exemplo, os «alimentos» prestados ao filho num períolo em que ele viva lora da casa dos pais). Na opiniáo dominante, mas näo indispulada, o $\$ 1 / 0$ constitui um caso especial de aplicação do \$ 107 , uma hipótese de autorizaçä́ concludente, e nâo propriamente una extensăo da capacidade negocial (como ocore nos \$ 112 e 113 ). Note-se lodavia que o $\$ 10$ apenas respeila a «negócio obrigacional», näo tequlando a eficácia do «negócio de disposiçäo ou cumprimentos (a aferir nos termos do $\$ 107$ ). Ver sobre esta temática, pondo em destaque as implicaçós dos distintos entendimen tos sobre os aspectos apontados, o lamoso «Lottericlall», Reichgericht, Re $/ 7,74,234$ : un estudante, entăo com derasiete anos, comprou, sem assentimento do pai, un carro por 3200 Marcos, pagando o preço com dinhciro proventente de uma hotaria que tiuha 
adquirido com os seus três Mareos de «semanada»; e prelende mais tarde a restituiçăo do preço e correspondentes jutos.

Seja como for, frisa se na doutrina alemà, o espaço de autodetcrminação ceonónica c negocial assim concedido, que permite ao menor remir experiência de participaçăo no tráfico juŕdico, sem prejúzo da protecéão do seu palrimónio, em termos que servem anda a competencia educativa dos pais. Contudo, sobretudo para inenores a parti de uma cona idade näo deixa de causar estranheza que al efić́cia dos negócios por ele concluidos, respeitantes aos necessaries, esteja dependente do assentimento, anda que concludente, dos pais.

Nos termos dos $\$ \$ 112,113$, a capacidade negocial (e processual) do menor é (parcialmente) ampliada a chamada Landelsmiindigkeit e Arbeitsmändigkeit-onde os representantes legais o autorizaram a exercer autonomanente uma actividade comercial, um «Erwerbgeschäft» (hipótese en que é, além disso, necessária a auborizaçao do tribunal), ou uma actividade profissional ou laboral. Thata-se de uma decisão discricionária dos pais, não suprível judicialmente (clis, porem, \$113111) e «revogível» (requerendo-se, porém, para a revogaçăo, a anuencia do tribunal). A autorizaço comporta a faculdade de o menor realizal os «negócios conexos» com a actividade excrida. li, se concedida para um concrelo caso, estende-se, na dúvida, a actividades semethantes ( $\$ 113$ IV).

Merece ainda atenção a circunstância de, no direito alemão, a restituição das presta çŏes realizadas em cumprimento de um negócio ineficaz (para o que aqui interessa, cm razäo da incapacidade de um dos contraentes) seguir as regras do enriquecimento sem causa, ou seja, da condictio indebiii. Desse modo, a obrigação de restituição está, em princípio, limitada ao enriquecimento «actual», segundo o $\$ 818$ III.

Contudo, o\$819 I preve uma responsabilidade agravada do enriquecido, que passará a ter de restituir o que recebeu, independentemente do seu eventual percimento, de terioraça ou consumo, quando tinha conhecimento, ou o veio a obter posteriormente, da «falla de causa». Discute-se, entấ, se se deve atender ao conhecimento do menor (e năo apcnas ao dos representantes, por viat de uma analogia com o disposto no $\$ 160$ 1) para efeito da restituição do que ele haja recebido no cumprimento de um negócio inelicaz conclú́do pelo próprio. Ver, sobre isto, a decisăo do Bundesgerichtshof, BGHZ. 55, págs. 126 ess., no lamoso «lugreisefall»: um menor, com 17 anos, conscguiu viajar sem bilhele num voo da Alemauha para Nova lorque (sobre a discussão suscitada pela decisäo consultar, cntre muitos, CANARIS, IZ, 1971 , pág. 600 ess.). Advirta-se, porém, que na lipotese referida se tratava de uma «lingriffiskondiktion», donde ter entendido o tribunal, e parte da doutrina, serem aplicáveis, constatada a analogia das situaçöes, as regras da imputabilidade delitual (soluçăo tanto mais incerta quanto o voo cstava esgotado, c, portanto, dificilmente se podia diser que da actuação do menor resultou um dano para a companhia aćra).

Para além disso, se o enriquecimento do menor já näo se verifica actuabuente, ou se dá em menor medida, e lal circunstância é invocável, põe-se a questĩo subsequente da aplicaçä́o da «Saldotheorie». Defende tal teoria, comummente adoptada, que à obrigaçăo de restituir há-de ser «deduzido», em atençăo ao sinalagma operante mesmo nos contratos mulos ou ineficazes (por vezes denominado «sinalagma fáctico»), o valor 
da prestação recebida pela contraparte, abstraindo da medida do locupletamento actual. No limite, isso pode tradurir se, em termos práticos ou conómicos, em manter os eleifos contratuas. O que, no caso da obrigacão de restituiçäo pela contraparte de uma prestaçäo recebida com basc num contrato inelicaz porque celcbrado por un menot, condur a um resultado contraditório com a protecęaro que a este a lei quer conceder. Donde a rejeiçáo da «Saldotheoric» nessas hipóteses, fazendo-se, portanto, recair sobre a outra parte inclusive o risco do perecimento da sua prestaçăo.

Por último, assinale se que, de um modo geal, onde o menor năo possa participar aufonomamente no tráfico jurídico, os seus represcntantes legais detêm amplos posteres de representação (pata os pais, cef $\$ \$ 1629$ e ss.). Porém, em virtude do $\$ 1629$ a (cuja redacęa actual resulta de uma alteraço legal de 1999), a responsabilidade do menor por dívidas on vinculaçoces assumidas pelos seus reptesentantes (ou por outris pessoas mas com cfeiros para o menot, ou por cle próprio com assentimento dos representantes) ou derivadas de uma acuisiçăo por sucessăo mortis causa csía limitada aos bens per rencentes ao património do menor à alua da maioridade (note-se que, no dircito português, a prolecęão do património do menor já resultará, cm larga medida, da necessidade de autorizaça do tribunal para os pais poderem paticar os actos enumerados no art. 1889."). Semelhante limitaçăo da responsabilidade năo se aplica, porém, no âmbito de uma actividade comercial (no direilo portugues, ver o disposto no n." 2 do art. 127.") que aquele tenta sido autorizado a exereer, nem para negócios que tenham servicto a satislaçã̃o das suas necessidades pessoais.

Uma preocupaça similat de circunscrever «responsabilidades nuinosas», embora num contex to bem difercute, levou à alteração do $\$ 828$, que se ocupa da responsabilidade civil do menor, em 1/08/2002 (concuanto a redação actual resulte de uma lei de $6 / 04 / 2004$; note-se que a altenaçõo näo terá alastado totalnente as objeçoos anteriomente levantadas, e de que à frente, em parte, se dará conta). De facto, colocavam-se (cfr. CANARIS, loce (ii.) algumas dúvidas quanto à constitucionalidade do \$ 82811 , na sua versä̀ anterior, por consagrar uma responsabilidade ilimitada dos menores já por actuaçoes nogligentes (recorde-se que o BGilb năo contén nenhuma norma, semelhante ao art. 4.94." do (Co. digo Civil, (que preveja a limitação da indemnização en caso de mera culpa).

Depois da alteração aludida (acompanhada pela modificação do \$ 7 II SivG e do \$ 11 Haftpllo, que substifúram como causa da exclusão da responsabilidade o «unabwendbates Ereignis» pelo «höhere Gewalt» - conceitos que se aproximaräo, respectivamente, do nosso «caso fortuito» e «caso de força máior»), o sistema alemão da tesponsabilidade delitual dos menotes apresenta um quadro relativamente diferen ciado em funçăo de três «escalöes ctátios».

Primeiro, estabclece-se que quen tiver menos de sele anos não é responsável pelos damos que cause, (arece, pottanto, de «capacidade delitual» (\$828I).

Poroutro lado, tăo pouco quem liver entre sete dez anos responde pelos danos que provoque negligentementenumacidente comum veículo automóvel, com um «vé́culosobre carris» ou com um «monocamil» ou «teletérico». Fstá subjacente a semelhante preceito (\$829 II), que estende «sectorialmente» 0 «privilégio» da falta de imputabilidade atribúdo aos menores com menos de sete anos, o reconhecimento, com base na psicologia do descuvolvimento, deque ascrianças antes dos dezanosnäoestäo, por rega, cncondiçóes 
de se apercebceme avaliatem correctanente as sifuaçes (designadamente, distancias c velocidades) e perigos increntes à circulação rodoviaria motorizada. De acodo com a finalidade de proteçăo da norma, apenas se contemplam os acidentes com véculos em circulaça e os danos resultantes do perigo especial que envolve a utilizaçăo de vérulos motorizados. İ da uexcepeão de irtesponsabilidade» estäo ainda expressalmente (\$ 8291112 ) exclúdos os danos causados dolosamente pelo menor com mais de sete anos (por exemplo, se este se «diverte» a atirar pedras aos carros que passam).

A importancia de lal disposição, decorrente da alteraçăo introduzida, decorre ainda de os seus pressupostos serem aplicáveis às relaçoes obrigationais (responsabilidade do (levedor), por remissão do \$\$ 276 I 3, e no âmbito da «conculpabilidade do lesado» (\$254; assim, por exemplo, a «eulpa» da crianca, com menos de de anos, que alraves sa a rua distrấda, a correr, e ćatropelada, näo será tomada em conta para atcnuar a obrigação de indemnizar do lesante).

Por sua vez, os menores cuja imputabilidade näo esteja alastada (pelo \$ 829) I, II) não serăo responsáveis se, no momento da prática do facto, näo tiverem «o entendimento necessário para reconhecerem a responsabilidade» («dic zur Frkenntuis der Verantwortlichkeit crforderliche Einsicht»). Assume, pois, importância decisiva a «Einsichtsfïhigkcil», apreciada in concreto. A jurisprudencia lança aqui mấo da seguinte fómula (inuito livremente traduzida): «possuirá o entendimento necessário (juem tenha alcançado a maturidade ou desenvolvimento mental ou intelectual que o torte apto a reconhecer a ilicitude da sua actuaçáo e, simulaneamente, o dever de responder, de algum modo, pelas conscequência dos seus actos». Ressalta que só está, segundo a lera da lei e a sua interpretaçâo jurisprudencial, em causa o elemento intelectivo («intellekfuelle Hähigkeit»), isto é, a capacidade de «reconhecinento», e já não o elemento volitivo, a possibilidade de se oricntar por tal «reconbecimento» («Stencrungsfähigkeit»). Lste segundo aspecto fica relegado para a apreciação da culpa (no âmbito do \$276). No contexto desia, importa fodavia notar que o grau de diligência requerido ao menor, na apreciação da sua culpa ou conculpabilidade, seguira un critério objectivo e lipificado, mas adaplado à sua «classe cláriàs.

Por último, refira-se que o $\$ 829$ do BCiB prevê uma responsabilidade especial do inimputável, quando razóes de equidade o imponhan (fala-se mesmo de uma «Billigkeiishaftung»), e não seja possível obter a indemuização das pessoas obrigadas a vigiá-lo. Que, por sua ve a culpa da parte das pessoas obrigadas a vigiar outrem, quer o nexo causal entre a inobservância de tal dever c os danos causados (cm moldes muito próximos, cfr. art. 494." do nosso Código (ivil).

Porém, a relação entre o $\$ 82811$ e o $\$ 829$ c ainda alvo de discussâo, acentuando algums autores que se corre o riseo, com uma aplicação «generosà deste álimo, de «deixar cntrar pela jancla, aquilo a que o legislador fechou a porta através da alteraçá introduzida no \$ $828 »$.

Sobre o direito alcmäo, consultar, entre nuitos, K. I ARENZ / M. WOLF, op. cit. págs. 119 e ss., H. BROX, Allgemeiner Teil des BGB, Kölı, 2004, págs. 125 c ss.,

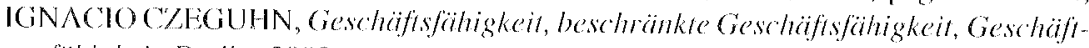
sunfihigkeit, Berlin, 2003. 
A regulamentação legal vai getalmente justificada apenas com a referência à «protecção do menor». Issta indicação parece, todavia, demasiado indiferenciada para servir de critério a soluçōes concretas, e pode condurir a uma restrição inconveniente do modo de consideraro problema subjacente: ao lado do interesse do próprio incapaz, há que ponderar o interesse dos pais ou representantes legais, a tutela da contraparte e as exigências do tráfico jurídico ${ }^{18}$.

Antes de tudo, a un nível mais geral, deve acentuar-sc o incindível nexo entre a autonomia (privada), como possibilidade de conformação das relaçós jurídicas por livre vontade dos particulares, e a capacidade (de exercício $)^{10}$. Não tem sentido falar em autonomia, não estando a pessoa em causa, a priori, em condições de entender complelamente a relevancia dos seus actos, de reconhecer correctamente os seus interesses, valorá-los, e escolher os meios adequados à sua satisfação. A autonomia privada, assim como a «responsabilidade» que the anda associada, bascia-se na «aptidão» para uma decisão livre e racional. Esta 《idoncidade» (ou «competência») é pressuposto indispensável da possibilidade de vinculação (negocial) pessoal $20 / 21 / 22$.

18 Assim já REINDI, JBI, 1970, pág. 64. Cfr ainda HELMUT KÖHIJR, JZ, 1983,
pág. 225. Em geral, numa perspectiva de dircilo comparado, REINHART SCHENK, Die rechtliche Fiahigkeit Minderjähriger, Bonn, 1970.

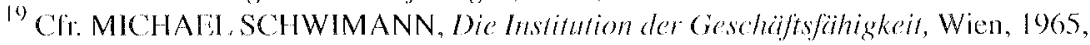
passim.

20) Năo terí entre nós cabimento a ideia de uma responsabilidade negocial derivada de um «mero comportamento láctico», nos termos da conhecida teoria das «retaçóes contratuais de facto». Es ainda que se admita a relevancia (negocial) de centos comportamentos sociatis lípicos no âubito do comércio massificado de bens e serviços (onde se poderá, talvez, cncontrar algum préstimo para a figura), haverá, para os menores, que conceder primaria ao interesse da sua proteç̧ão que sobrepuja, na valơação da lei, os demais.

21 Distinta da «capacidade negocial» é, como já se fez notar, a imputabilidade ou uca. pacidade de culpas (Verschildensfïhigkeit, mais em geral, falap-sén de capacidade delitual, abrangendo as várias modalidades de responsabilidade civil). Aí a lei, no art. 494.", basta-se com a capacidade de entender e querer (no domínio da respotrabilidade pelo risco os critérios de imputação são, claro, outros).

Merece a pena observar aqui duas ou três coisas acerca da responsabilidade civil por factos ilícitos dos menores no direito português.

Desde logo, constata-se que o «limite etário» dos sete anos previsto no n." 2 do art. 488 ." não representa, estritanente, uma barreira lixa abaixo da qual se isente o menor de responsabilidade (ao contrário do direito alemăo, onde, de resto, se foma igualmente como ponto de referencia a idade de sete anos, eft. \$ 828 I BGB; e do direito austríaco, 
conquanto este fixe a imputabilidade nos catorze anos, cfr. $\$ \$ 1308-1310$, cm ligaçäo com o \$2 I II $\triangle \mathrm{BGB}$ ). A norma em causa estabelece meramente uma presunçăo ilidível de fata de imputabilidade para crianças com menos de sete anos. Donde que mesmo estas sejam responsáveis se se demonstrar que, no caso, eam imputáveis no momento da prática do facto danoso. Demais, é quase supérftuo advertimo, do mesmo preceito năo se relira que quem tem mais de scte anos possui sempre o discernimento bastante para responder delitualmente.

Cabe, porén, notar que a responsabilidade do menor impulável é susceptível de ser limitada ou excluída, nos temos gerais, do art. 494.", se ele não actuou dolosamente. Por outro lado, podem cumular-se a responsabilidade do menor e a da pessoa obrigada à sua vigilância (cit. art. 497."). Como ensina ANTUNISS VAREI A, Dirciro das obrigaçoses, I, Coimbra 1986, págs. 562, os conceitos de incapacidade natural e de inimputabilidade năo correspondem necessariamente. Duvidoso afigura-se, todavia, que exista aqui, como afima o mesmo autor, uma solidariedade (perleita) entre ambos os obrigados (nomeadamente, o menor só deverá poder ser demandado pelo tereeiro nos termos da sua responsabilidade individual; vide ainda $i n / r a$ ).

Diferente da constatação da imputabilidade é a questäo ulterior do criterio de aferição da culpa do menor, do grau de diligência que se lhe possa exigir. Parece, como acentua a melhor doutrina (cfr., por todos, ANTUNES VAREL A op. cit., págs. 547 e ss.), que a apreciaçăo da culpa in abstraco, pela bitola da diligencia de um bom pai de família, culminando no seu entendimento como conduta deficiente e năo simples deficiência da vontade, scgundo o art. 487.", n." 2, näo se opoe a que se atenda, para aferir dos conhecimentos, capacidades c aplidões objectivamente exigíveis, à inserçâo profissional, e a outras características ou qualidades do agente, nomeadamente à sua idade.

Ao lado disto, há que assinalar que a «culpa» do menor lesado, na produção ou no agravamento do dano, será atendida, nos termos do art. 570.", para a redução da indemnizaçăo ou mesmo para a sua eventuat exclusão. O que, eventualmente, pode pôr en causa a necessária proteção do menor (rectias, das crianças; e cm geral dos chamados «esados frágeis», que justamente carecem de especial tutela). Näo nos termos do n." I do art. 570.", pois aí o tribunal dispōe de amplo espaço de decisão aberto pela consideração da gravidade das culpas concomentes e das respectivas consequências (descle que não se entenda bastar uma concausalidade por parte do lesado, que até prescinda da imputabilidade deste). Mas, isso sini, no domínio do n." 2 do mesmo preceito, onde a culpa do lesado exclui a responsabilidade que se baseie numa presunção de culpa e, por maioria de razão, segundo a doutrina e a jurisprudência ainda dominantes, a responsatilidade pelo risco, em especial, em matéria de acidentes de viação (art. 505."), e mesmo tatando-se de un facto de um inimputável.

Solução essa que não se afigura feliz c que foi expressamente afastada, como se viu, na lei alemã para menores com menos de catore anos. Li já muito anteriormente o fora na lei francesa (näo obstante esta última, no art. 489-2 do Code Civil, em termos gerais prescindir da capacidade de discemimento comopressuposto de responsabilidade). Com efeito, em liranģa, desde a chamada l oi Badinter, de 1985, quanto aos danos pessoais, e face a terceiros, isto é, excluindo o condutor, só se atribui relevância a uma «aute inexcusable» da vítima c apenas quando cla represente a causa exclusiva do acidente 
(a «aute inexcusable» do lesado permanece assim irrelevante se houve culpa do condutor ou detentor do vé́culo). Fi a relevância da «culpa do lesado» está de todo arredada para os «superprivilégićs», as «victimes irréprochables», isto é, os menores de dezasseis anos, idosos com mais de setenta e incapacitados permanentes ou com invalidez superior a $80 \%$. Com a excepção, que opera em todos os casos, da chamada «faute volontaire».. restius «faute intentionelle»--, por exemplo, tentativa de suicídio. Sobre isto, recentenente, deplorando a orienlação da jurisprudência portuguesa que alinha pela orientação acima criticada, BRANDÃO PROBNC A, Responsabilidade pelo risco do detentor do verculo e conduta do kesado: a lógica do «tudo ou nades»?, CDP, n." 7, 2004, págs. 19 ess.).

Acresce que, no nosso direito, de acordo com o art. 571.", a culpa dos representantes legais está equiparada ao lacto culposo do lesado. Assim, a inobservância do dever de vigilância por parte dos pais é imputada, como «culpa» própria, ao menor (mesmo inimputável) lesado. Tão-pouco tal disposiçăo se mostra muito acertada: carece de verdadeira justificação material e conduz a resultados inapropriados (o que é manilestamente o caso, se se impular ao menor a "culpa presumida» dos pais, da qual num eventual «direito de regresso» cle năo se pode prevalecer em relação àqueles, por se entender que art. 491." apenas se refere aos danos causados a terceiros, já năo aos sofridos pela pessoa que deve ser vigiada). Clr., em geral, e por lodos, CHRISTIAN V. BAR, Gemeinemopäisches Deliktsrecht, Band I, München, 1996, págs. 75 e ss.; c, sobre a questão da «culpa» do menor lesado, BR ANDÄO PROENÇA, A condua do lesado como pressaposto é critério de impataço do dano extracontratual, Coimbra, 1997 , cspecialmente págs. $713 \mathrm{css.}, 742 \mathrm{ess}$ e $785 \mathrm{css}$.

Por último, convém notar que, nos termos do art. 489.", apesar de inimputável, o menor pode ser obrigado a indemnizar, por motivos de equidade, os danos que lemha causado. O que configura, no entanto, una responsabilidade meramente subsidiária, isto 6 , que só existe se for inpossível obter a reparação das pessoas sobre as quas recai um dever de vigilância (nos ternos do ant. 49)."). Discute-se, porém, se se tem de tratar de unna impossibilidade jurídica (ocorrendo a clisão da presunção de culpa in vigilando ou a prova de que o dano se teria igualmente verificado ainda que o dever de vigilancia tivesse sido cumprido - ressalva contida no art. 491." in fine) ou se também está abrangida uma (mera) impossibilidade prática, advinda da insuficiência do palrimónio ou insolvabilidade dos pais.

Seja como for, a responsabilidade instituída no art. 489." não alcança mais do que os termos em que o lesante responderia se fosse imputável quando praticasse o facto (doutro modo, seria ele tratado de modo mais desfavorável do que um imputável: há quem fale aqui de uma «culpa objectiva ou absiracta»). Näo se trata, pois, de uma responsabili dade objectiva (de fora ficam os danos provenientes de caso fortuito ou de loreca maior), nem tăo-pouco se prescinde da ilicitude da actuaçăo do agente.

Finalmente, mas não menos importante, a obrigação de indemnizar não deve ser fixada de molde a privar o inimpulável «dos alimentos necessálios $\mid \ldots 1$, nem dos meios indispensáveis para cumprit os seus deveres legais de alimentos's (art. 489.", n."2, in fine). No que se atenderá ao estado e condição social do imimputável, não se tratando apenas de lhe assegurar o estritamente necessário. 
As consideraçōes seguintes pretendem, pois, discriminar, em tosco esquisso, os vários e, por vezes, divergentes interesses presentes na regulamentação da incapacidade dos menores e a respectiva composição ou «quadrícula» legal no âmbito do direito civil.

\section{PRO'TECÇ̃̃O DO INTERESSE DO MENOR}

O interesse precípuo por trás da cominação da anulabilidade dos negócios celcbrados pelo menor reside, sem dúvida, na protecção do próprio. A sua incapacidade insere-se, pois, dentro das «incapacités de protection» (por oposição às «incapacités de défiance», nas expressões cunhadas pela doutrina francesa).

Mais aprofundamente, pode distinguir-se aqui uma dupla finalidade.

Por um lado, impõe-se preservar o incapaz, em atenção à sua menor maturidade psíquica e experiência da vida, de prejuízos, pessoais ou patrimoniais, que ele possa causar a si próprio ou que resultem da actuação de terceiros em detrimento dele (explorando a sua imaturidade).

22 Quanto à responsabilidade pré-negocial (art. 227."), sustenta-se geralmente, entre nós, que o menor náo responde com esse fundamento, surgindo porén divergências na justificação de uma tal soluçāo (que, aliás, suscitará dificuldades a quem defenda uma natureza extracontratual para a culpa in confrahendo). Diferentes são acpucles casos cm que o seu comportamento, violando uma disposiçäo legal, penal - por exemplo, na hipótese de burla, onde, de resto, anda se requererá a imputabilidade penal - ou de outra índole, o constitua em responsabilidade civil, nos termos do arts. 483." ess. 1: lambém nas hipóteses do art. 127\%, haverá que responsabilizar por cic o menor. Por outro lado, nada parece obstar, no nosso direito, a uma responsabilização por cir face ao menor. (fr., por fodos, BAPTISTA MACHADO, RLJ n." 3726, pás. 266, e, para o dircito alemão, CANARIS, NJW, 1964, pág. 1988; em sentido dilerente, porćm, G. KÜPPERSBUSCH, Dic Hafinng des Minderjährigen fïr culpa in contrachdo, 1973.

O problema que vimos referindo coloca-se ainda quando o menor assuma a qualidade de procurador (ou de núncio) scm deter os necessários poderes (ou havendonegligência ou dolo na transmišão da declaração), pois, como se sabe, a responsabilidade do falsus procurator (e do múncio «infiel») filia-se no art. 227." Recorde-se que, nos termos do art. 263.", o procurador não carce de capacidade de exercício, bastando a capacidade de entender e querer cotrespondente à substância do negócio (ao núncio nem essa «capacidade» se exigirá). $\Lambda$ justificação de tal norma encontra-se precisamente no laclo de o representante não ficar nunca vinculado ao negócio que realiza (cm nome de oufrem). Por sua vez, o dominus, ncesssariamente capaz, sibi imputet se escolheu um menor para seu procurador: Também a responsabilidade do incapaz que assuma a gestão de negócio alheio (a jul zar se que para o efcito não se requer capacidade negocial) estará em princípio exclúda ou atcnuada, näo seguindo, portanto, as regras dos arts. 46.5." e 466.". 
Por outro, deve, na medida do possível, ser-lhe permitida uma participação activa c independente no tráfico jurídico-negocial. Esta finalidade educacional ou pedagógica realiza-a a lei pela cominação da (mera) anulabilidade como consequência para os actos praticados - por conseguinte, os seus actos consideram-se eficazes, anda que porventura de mancira provisória ou interina ${ }^{23}$-, e pela consagração de excepçôes relativamente latas a cssa incapacidade (cfr. art. 127." ${ }^{\circ}$ ) - existindo assim espaço para que se vá preparando, gradualmente, o ingresso ou inserção plena no tráfico jurídico normal com a entrada no umbral da idade adultas.

${ }^{23}$ Na prática, visto a anulabilidade só poder ser invocada pelo lado do menor, isso sig. nifica (jue a «sorte» do negócio, a stla subsistência, fica inteiramente ao criterio dos scus representantes e do próprio quando chega a maior (e, a năo haver uma confirmaçăo, durante um perírdo de lempo porventura demasiado longo, vide infira).

Conquanto, não maro, os representantes do menor ou este, por «comodidade», «receio de litigar» ou simplesmente ignorância, deixaräo subsistir o negócio (inclusive cum prindo-o e, portanto, confirmando-o). Para isso poderá ainda contribuir a circunstância de a anulabilidade ter, no nosso sistema, de ser feila valer judicialmente (o gue, porém, assume significado sobretudo se o negócio foi cumprido).

${ }^{24}$ A que se juntarao, obviamente, outras excepçöes dispersas peda lei, sobretudo no contexto de negócios de cariz pessoal (a que em parte já se aludiu).

25 Naquilo a que se pode chamar um «estágio preparatório para a vida adulta», e onde se inserira, dentro de cortos limites, uma aprendizagem com os próprios cros ou equívocos.

Vejanos mais de petto o conteúdo da al b) do n." I do ant 127. Dispoe tal moma serem válidos os «negócios jurídicos próprios da vida corrente do menor, cue, estando a) aleance da sua capacidade natural, só impliquem despesas, ou disposiçöes de bens, de pequena importâncià. Pode encontrar-se aqui un cetto coo, malgado diferenças importantes deste logo, a disfancia que vai dos «negócios proprios da vida cotrente» àqueles que são necessários a asscgurar o «mínimo existencial» ou o «standard social», da doutrina anglo saxónica dos necessaries (e também dificuldades com paráveis de aplicaçäo). Por regra, a «capacidacte natural» do menot evoluirá com a idade, permitindo the progressivamente aceder a uma actividade negocial (autónoma) mais ampla. A lei exige ainda, em todo o caso, e para conter um eventual dano para o menor, que se trate de um negócio da vida corrente, envolvendo uma despesa de pequena importância.

Segundo PIRES DE I IMA / ANTUNTSS VARLIA. Código Civil Anotado, vol. I, Coimbra 1987, anotaço alo art. 127.", a apreciaçäo de tais quesitos fica, em larga medida, entregue ao prudente critério do julgador que terá em conta as circunstancias de cacla caso. Donde resula, sem dúvida, alguma margem de incerteza e insegurança (tanto mais que tais circunstânciass säo, muitas veres, inacessiveis à contraparte). 


\section{PROTECÇÃO DO CONTEÚDO DO PODER PATERNAL E DO PODER DE TUTELA}

Mas importa, por outra banda, acentuar o ligame entre a regulamentação da condição jurídica dos menores e o conteúdo do poder paternal $^{26}$. Designadamente, o poder paternal só pode exercer na plenitude a sua função quando o menor a ele não se possa subtrair, por sistema, através de vinculaçoes negociais válidas ou não impugnáveis (sendo evidente que as relaçoes entre o menor e os pais, na complexidade da vida familiar, não se deixam reduzir à protecção daquele e ao suprimento da sua incapacidade, muito menos se esta última é referida preferencialmente ao domínio negocial). Além disso, porventura interesses próprios dos pais serão afectados: haja em vista as regras relativas à administração dos bens e rendimentos dos filhos (cfir, mormente, art. 1896.", c ainda art. 1895.").

Porém, un critério «objectivo», obedecendo ao uentendimento nomal» no trático jurídico, pode nẫo se mostrar läo eficaz na protecção do menor (notar-sc-á, a este propósito, que no direito alemão, no \& $105 a$ BGiB, onde os pressupostos da eficácia dos negócios próprios da «vida corrente» do incape sấo entendidos do maneira «objectiva», se excluem as sifuaçöes onde exista perigo relevante pata a pessoa ou património (lacuele).

Duvidoso śanda que, dentro da latiude concedida pela lei, haja que atender (como também preconizam os autores atrás citados) à siluaçäo económica c social do menor para aferir da pecpuena ou grande importância da despesa realizada. A diferença de tratamento que dá resultaria, por exemplo entre um menof com um amplo património e um menos afortunado, é de molde a susciar algumas reservas.

Por outra banda, como sugere GUIL HEiRME DE OI IVLIRA, RI J, 11." 132, pág. 19, o previsto na al. b) do n." I do art. 127." (no texio citado, indica-se por lapso o n." 2 do art. 127."), cmbora aí se contemple apenas actos patrimoniais, é aplicável por analogia aos actos de natureza pessoal de pequeno relevo. Assim, ainda segundo o mesmo autor, un menor, de qualquer idade, pode prestar validamente consentimento para todos os acios de assistência médica de pequena importânciá, que estejam ao alcance da sua capacidade natural. Aqui se integrando, aliás, as formas de consentimento, para além da mera tolerância da intervenção, que envolvam compromissos jurídicos, por exemplo, serviço de desinfeçäo de mma ferida ligeira e o paganento módico por esse serviço.

26 Descrito no art. 1878.", n." 1, e que se pode desdobrar em poder pessoal e poder patrimonial, poder de representaçäo e poder de comando (cfr. por todos, CASTRO MENIDLS, Direito da Família, l isboa, 1979, págs. $103 \mathrm{css}$.). Atemomos, portanto, no texto, ao caso (típico) $\mathrm{cm}$ (jue a incapacidade dos menores é suprida pelo poder paternal (cfir: alt. 124."). 
Destarte, a possibilidade concedida aos progenitores, hos termos do art. 125.", n." I, al. a), de suscitar a anulação dos negócios jurídicos celebrados pelo filho representa, quer um meio ou expediente técnico-jurídico de realização da proteçãáo do menor, quer, por outro lado e concomitantemente, uma forma de preservar os direitos-deveres que integram o poder paternal ${ }^{2 \%}$.

Donde não se afigurar absolutamente correcta a afirmação de que «só o menor tem o direito de anular, $|\ldots|$ quanto ao representante legal, a sua posição analisa-se num problema de legilimidade e não de titularidades (Carvarno Frirnandris). Mas o problema permanece de construção conceptual, desde que daí não se queira inferir directamente consequências de regime.

As consideraçôes expendidas poderão ter também alguma valia para aclarar se a preclusão do direito de anular o acto, no qual o menor tenha usado de dolo, fazendo-se passar por maior ou cmancipado (art. 126."), se estende alos representantes legais, ou seja, às pessoas referidas na al. a) do n." I do art. 125.". A solução, segundo a quál aos representantes legais não fica coarctada a possibilidade de suscitar a anulação, parece resultar da letra do art. 126.", cotejado com o texto preparatório que the serviu de base (da autoria de Gomes da Silva); lal argumento está, porém, longe de ser decisivo ${ }^{28}$.

${ }^{27}$ Un aspecto merece, neste âmbilo, voltar a ser realçado: a extensão do circulo das excepecoes à incapacidade dos menores pode ter cfeitos delctérios sobre o exercício do poder paternal, tendendo a restringir o seu conleúdo. Opere-se tal alarganento por via legislativa ou por via interpretativa, $v$. g. nas l eis do Trabalho, ou como sucede, pelo menos segurdo o seu teor literal, no art. 5." da l ee n." 3/84 Educaçá sexual e planea mento familiar (ctr. ainda a Portaria 52/85, de 26/I, que aprovou o Regulamento das Consultas de Planeamento familiar e Centros de Alendimento para Jovens, e previa o acesso «sem qualquer restriçăo» de «lodos os jovens em idade fértil»).

Aqui entronca ainda a (questäo - a que julgamos ser de dar, em termos gerais, resposta afur mativa, sem prejuizo, lodavia, do disposto no art. 1881.", 11." I, a interpetar con temos hábeis - de saber se o poder de representaçăo dos pais se manterá quanto a actos que estejam comprendidos no âmbito das excepçoes à incapacidade do menor. Porém, yuanto aos bens que, nos termos al. a) do art. 127.", o nenor com mais de dezasseis anos pode administrar e dispor, a al. d) do no" I do art. 1888." exclui, expressamente, os pais da sua administraçăo.

${ }^{28}$ Não se deixará de notar que bem fruste será a protecȩấo da contrapate se se entender que os representantes legais podem arguir a anulabilidade. Com efeito, no comum dos casos, sắo estes que pöem em causa os negócios celebrados pelo menor (e năo o próprio, uma vez. maicor). 


\section{TUTELA DA CONTRAPARTE E DAS EXIGENNCIAS DO TRÁFICO JURIDICO}

Consabidamente, a simples crença de boa fé ou conliança e de que alguém é capaz não encontra protecção na lei. Fio o menor tomado por maior ou cmancipado, inclusive porque ludo o indiciava, tendo a contraparte usiado da diligência devida, ou até mesmo por inculca do incapaz (vide infra a propósito da caracterização do «dolo»), essa confiança näo sobreleva o interesse de protecção do menor ${ }^{29 / 30}$.

E acentuar-se-á que a anulação do negócio não depende da prova de um prejuízo sofrido (ou, se se quiser, cste presume-se in re ipsa ${ }^{31}$; cm casos-limite, uma eventual «paralisação» do dircito de anulação por consubstanciar um abuso, nos termos do art. 334.", não é, porém, de excluir).

29 Demais, a contraparte está ainda, porventura, exposta an risco da anulaçắo da prestação que tenha recibido (nos krmos do n." I do ant. 764.") e de fer de prestar novantente (de acordo comon." 2 do art. 764."). Vide infra.

30 Perguntarse-á, porém, so a contraparte, que negoceia con o menor, supondo-o maior, não se poderá soconer da relevância do seu cro, reforido à pessoa do declaratário, nos termos do art. 251." (ou mesmo do dolo, nos termos dos ar1s. 253." e 254."). Alguma doutrina exclui tal possibilidade por enicnder que se trata, nesses casos, de um «ero impróprio». llá também quem defenda que, nesta questäo,o regime da menoridade alasla a aplicaçấo das regas gerais relativas ao erro. Ao invés, outros autores năo encontram razo suficicnte para não aplicar tás normas. Uma tese «intemédia» faz relevar, em geral, o crro sobre a idade, designadanente sobre a maio-ridade, mas näro quando a essencialidade de lal coro contenda apenas com o facto de, por essa razäo, o negócio ser anulável.

OCode Civil frances, no art. 1125, dispoe expressamente que a contraparte, que contra$10 u$ com un incapaz, näo se pode prevalecer de lal circunstância.

31 Diferentemente no dircito francês. Aí, a lei considera incapazes (cfr. arts. 1123 e 1124 do Code (Civil), «dans la mesure définic par la loi», de contratar os menores (isio é, quem tem menos de dezoito anos, arts. 388 e 488 do Code Civil). Porém, segundo o art. 481 do Code Civil, o menor emancipado (pelo casamento ou judicialmente, cfr. art. 477) sapar, como um maior, para todos os actos da vida civit, exceptuando o casamento e a adopçấo; ressisalva-se anda a impossibilidade de o emancipado ser comerciante. Correspondentemente, cessat a «autoridade do pai e da mãe» (art. 482).

A «capacidade de contratar» constiut uma condiçáo de validade dum negócio on contrato (art 1108 do Code (ivi)). Mais en concreto, se se trala de um acto que o próprio representante näo podia, em vista da sua gravidade ou alcance $1 . g$. venda de $u m$ imóvel, empréstimo, renúncia a um direito -, ele próprio realizar sem estar especiatmente attorizado, isto ć, scm a anuência do cônjuge, a autorikação do tribunal ou do 
consetho de família, o acto praticado pelo menor (não emancipado) é, sem mais (sem necessidade de mostração de qualquet prejuízo), anulável.

A anulação ocorrerá a instância do representante legal ou do menor, entretanto maiot ou comancipado. Li estará precludida se existiu «dolo», o que requer «manouvres doleuses» ou «dolosives» com o intuito de fazer crer à contraparte que está perante um maior (conquanto näo exista uma disposição que expressamente consagre o «mantien du contrat» no caso de dolo do menor, tal soluçăo extrai-se dos arts. 1307 e 1310 ). 0 prazo de prescriçăo do direito de anulação é de cinco anos, confados a pattir da maioridade ou cmancipaçăo (clt. alt. 1304 do Code Civil). Anulado o acto, os seus efeitos serão removidos relroactivamente. Contudo, o menor só terá que restiluir aquilo de que efectivamente bencficion (ver alt. 1312, c ainda art. 1241, regra que vale também no caso da «rescision», vide infia).

Se está en causa un acto susceptível de ser praticado pelo representante sem necessidade de qualquer «habilitaçäo», apenas pode ser pedida a «escision pour lésion» (cfr. ant. 1305 do Code Civil; năo obstante a Ietra do já referido art. 1108 , o legislador lancês quis aqui permanecer liet ao entendimento ladicional da jurisprudencia do «Ancien Droit», bascada na máxima do dircito romano «minor restituilur non tamquam minor, sed lamcuam laesus»), dentro de cinco anos apos a maioridade ou emancipação, e salvaguardada a possibilidade de «ratification» atingida a maioridade (art. 1311).

O que, embora se aplique à generalidade dos negócios, no diret do art. 1305 do Code Civil (comparar com o art. 1313, para os maiores), supốe a evidenciaçăo de un dese quilíbrio contratual (cujo limiar foi deixado à apreciaçăo do julgador), destavorável ao menor, tomada em conta a sua situação subjectiva, constatável à altura da conclusão) do negócio, com una incidencia global neste, e que, segundo o art. 1306, näo decorra de um evento casual e imprevisto. Por outro lado, há-de ainda o acto ter sido praticado por um menor năo «dépourvu de discenement» (sem que a lei trace aqui um qualquet limite etário).

Incólumes permanceem contudo os «actes usuels», isto é, aqueles que, segundo os asos e concepeóes actuais, se admite que possam ser praticados por alguén da idade do sujeito em causa (ver arts. 3893 e 4501 do Code Civil; que tais actos näo ic confinam, pelo menos depois da reforma de 1964, aos actos conservalótios ou de administração traduz o entendimento maioritário).

Exceptuam-se iguatmente da «lestituição» por «lésion» as vinculaçóes on obrigaçoes assumidas num eventual contrato de casamento (art. 1309 do Code Civil) e no âmbiro da profissăo exercida (art. 1308 do Code Civil). Deste último preceito exirai se, aliás, a relevante possibilidade de o menor exerece uma protissä́o, desde que näo conercial (art. 487, a fortiori).

Eum matéria extra-patrimonial, são vários os actos que a lei autoriza o menor a praticar. Entre muitos, por exemplo: consentimento para adopção a partit dos 13 anos (arts. 345, al. 3, c 360, al. 2); casancnto (com assentimento dos pais, art. 148); interrupçäo voluntária da gavides (art. I 162-7 Code de la Santé Publique). De resto, o domínio de aplicação da doutrina dos «actes usuels» também alcança os actos pessoais (por exem plo, o reconhecimento da paternidade).

Sobre o direito francés, ver, por último, BFRNARD TTYYSSIl, Droit Civil tees Per sonnes, Paris, 2005 , págs. 200 c ss. 
Deparamos neste ponto, aliás, com um traço do regime da menoridade comum à generalidade das legislaçóes civis ${ }^{32}$.

Tutelada é a confiança da contraparte, nos termos do art. 126." 33 , apenas quando o menor usou de dolo para se fazer passar por maior ou emancipado - malitia suplet aetatem (cfr. já Codex Justinianus 2, 42, 3 pr., Du(oclestano): conquanto o negócio seja anulável, a outra parte poderá excepcionar, alegando os factos constitutivos do comportamento doloso. Para caracterizar o dolo mostram-se aqui (ver ainda art. 253.") necessários artifícios, manobras ou sugestões de natureza fraudulenta (de «dolosa macchinazione» fala a jurisprudência italiana) ${ }^{34}$.

Como se constata, a proteç̧ão do menor tem precedencia sobre a proteç̧io da confiança e do tráfico jurídico. Não quer isto, todavia, significar que o nosso direito the conceda uma protecção absoluta, nem tal se mostraria apropriado.

Ocorre pensar num simples exemplo: um terceiro, que contrata com quem adquiriu do menor, estará protegido nos termos do art. 291. - também a anulação do negócio com base na incapacidade é inoponível a tercciro de boa fé ${ }^{35}$.

Em outros dois aspectos, que queremos destacar, transige a regulamentaçăo legal com os interesses da segurança e da clareza jurídica. Por um lado, a lei lixa, peremptoriamente, o término da incapacidade de excrcício derivada da menoridade (arts. $1300^{\circ} \mathrm{e} 133 .^{\circ}$ ), sem que importe de todo que, no caso concreto, o agora maior se cncontre efectivamente habilitado a reger a sua pessoa e a dispor dos seus bens ${ }^{36}$ (cir., porém, art. 131.0.37).

\footnotetext{
${ }^{32}$ Ver, por lodos, KONRAD ZWWIGIET / HLINZ DUETZ, op. rit., págs. 341 e s. Abra-se uma excepçäo para o direito istaclita que prevê não dever o contrato com $1 \mathrm{~m}$ menor ser declarado inváliclo se a contraparte não podia reconhecer cue contratava com um incapaz (salvo se da manutenção do contrato resultat para este relevante dano).

33 Que, pelo menos nos seus termos tão explícitos, só tem paralelo no art. 1426 do Codice Civile.

34 Relevasse a mera alirmação da maioridade, poderia a contraparte tornar, sem mais, o negócio näo impugnável, perguntando ao menor pela sua idade e obtendo deste uma resposia falsa. Diz expressamente o art. 1307 do Code Civil françês: «La simple déclaration de majorité, faite par le mineur, ne fait point obstacle a sa restitution».

Sobre o tema, em geral, JENS-PETER KURZ,WLLL Y, Die Haftumg Minderjahriger bei Tänschung iather die Geschäftsfahigkeit, Bomn, 1977.
} 
${ }^{35}$ Por outro lado, a proteção do menor é obtemperada pela impulaçăo das declaraçoes e actos negociais dos seus represcntantes legais: mesmo negócios jurídicos prejudiciais produzem efeitos para o menor, se realizados dentro do poder de representaçăo dos pais (cfi ant. $1881 . "$ ). Linites resultam aqui apenas da exclusäo da administraçáo do certos bens (att. 1888."), da necessidade de autorização do tribunal para certos actos (art. 1889."), e da cventual relevancia genérica do abuso de representaçầ (art. 260.") c da probibição do negócio consigo mesmo (art. 261.")

O menor responde ainda, segundo o art. 800.", pelos actos dos representantes legais no cumprimento das suas obrigaçoes, como se tais actos fossem praticados por cle (o que tem, claro, de ser entendido habilmente sendo o devedor um incapar). Já no domínio da responsabilidade extracontratual o menor náo é responsável pelos actos praticados pelos seus pais no âmbito do poder paternal (näo tendo cabimento a aplicaçăo do art. 500.0 ; clit, em todo o caso, o disposto no art. 571.", a que já aludimos).

${ }^{36}$ Que o legislador portugues (e a generalidade das legislaçöes) tenha prescindido de uma averiguação individual e castústica da capacidade de cada individuo decorre de um imperativo inarredável de certeza. Deve é perguntat-se se o interesse do trálico jurídico não será mais bem servido pela previsão de vários limites ctários, con consequências diferenciadas para os actos praticados pelo menor.

De resto, sobretudo fora do domínio dos negócios patrimoniais, a rigidez do sistema está já temperada por a lei atender frequentemente a diferentes «intervalos ou patamares clários». Neste contexto, a propósito das normas que concedem (plena) capacidade de decisão ao menor, fala sugestivamente GULLHERML, DE, OI IVEIRA de «maioridades especiais». Entre oulras hipóteses, considere-se as seguintes:

i) A partir dos sete anos, presumir-se-á a imputabilidade (delitual civil) do menor (art. 488.", n."2).

ii) Depois dos doze anos, é necessário para a adopção o consentimento do adoptando (al. a) do n." I do att. 1981."), c impöe-se a audição dos tilhos do adoptante também a partir dessa idade (al. a) do art. 1984.").

Por outro lado, a oposição do menor scrá tida em conba quanto à intervenção, no âmbito das medidas de protecęão, das entidades e das comissõos com connetêneia en matéria de infância e juventude (cti. art. 10." da I ci n." 147/9), de 1/09 Lei de Proteç̧ăo de Crianças e Jovens em Perigo).

F, nos termos do ant. 1." da Lei n." 166/90 l ce 'Tutelar Fiducativa "as medidas tutelares educativas são aplicáveis a menores com mais de doze anos (e menos de dezasseis), que hajam praticado un faclo qualificado como crime (cfr ainda arts. 42." n. ${ }^{\circ} 2,45^{\circ} \mathrm{e} 46 .{ }^{\prime}$ da mesma l ei, quanto à inciciativa, direitos e audiçäo do menor clurante oprocesso lutelar).

iii) Segundo o art. 38.", n." 3, do Códige Penal, cm termos gerais, o consentimento como causa de exclusão da ilicitude só é elicaz se prestado por quem tenha mais de catorze anos. Regra cue poderá ser transposta para o Direito Civil quando se trate de um uconsenti. mento tolerante», não estando, pois, en causa una verdadeira vinculagăo negocial. Assim, ORI ANDO DE CARVALHO, Teoria Geral do Negócio duridieo, polic., Coimbra, 1981 , págs. $183 \mathrm{c}$ ss., que distingue três tipos de consentimento - vinculante, autorizante

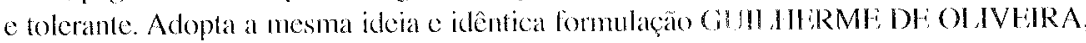


Ioc cit. a propósilo do acesso dos menores aos cuidados de saúde, fazendo notar que, nos demais aspectos para além da exclusão da ilicitude da intervençäo médica, os dechnores do poder palcmal conservario, en regra, os seus poderes, designadanente o poder de representaçio quanto a aclos jurídicos de que resultem obrigaçocs para ofilho-por exemplo, internamento hospitalar e pagamento dos honorários . por á se tatar de um «consentimento vinculante» ou «autorizante».

Desde os cáorze anos (aré essa idade só com autorizaçấo, por escrito, dos detentores do poder paternal) podem os menores constituit ou aderir a associaçöes e integrar os respectivos orgâsos (cfr. art. 2." da Lei n." 124/99, de 20/8; parece inclusive que tal disposiçäo se aplicará, com as imprescindiveis adaptaçóes, às associaçoes juvenis de partidos políticos, ato nada prever a csse respeito a I ci Orgânica n." 2/2003, de 22/8 ... I cei dos P'artidos Políicos, que revogou o Dec. 1 ei n." 595/74, de 7/11, e as suas alteraçöes subsequentes, eliminando portanto a disposiçăo al adrede prevista - art. 15.", n."2).

Noutro âmbito, o art. 1931." n."2, do Código Civil manda o tribunal, antes de proceder à nomeaçäo do tutor, «ouvir» (quer dizer, «escutar com um interesse real») o menor com mais do catorze anos. O mesmo devendo ocorrer, por rega, se os pais, em questöes de particular importância, näo conscguirem chegar a acordo quanto ao excrécio do poder paternal, art. 1901.", 11,"2.

iv) Prevista no art. 45." da Lei n." 147/99, de 1/09 - lei de Proteção de Crianças e Jovens en Perigo, a medida de apoio para a aubonomia da vida (que «consiste en proporcionar directamente ao jovem |... | apoio económico e acompanhamento psico-pedagógico e social, nomeadamente altavés do acesso a programas de formação, visando proporcionar-the condiçoes que o habilitem e the permitam viver por si só e adquirir progressivamente autonomia de viday) aplica-se a jovens com mais de quinte anos (excepcionalmente a mäes de idade inferior).

Por outro lado, em princípio, o adoptando há-de ter menos de quinze anos, nos termos do art. 1980.", n. 2.

iv) Dezasseis anos constitui a idade núbil c, potanto, também a idade a partir da (ual pode ocorrer a emancipaçâo (al. a) do 11."I do art. I60) I."). Marca igualmente o início da capacidade para perfilhar, scgundo o ant. 1850.". Por sua vez, o art. $1886 . "$ da ao maior de dezasseis anos poderes de decisão livere quanto à escolla da religiäo. No caso de tutela, pode o menor a partir dessa idade convocar o conselho de fanília (art. 1957.", 11." 1).

E representa ainda a idade mínima para se ser admitido a prestar trabalho (art. 55.", 10." 2, do Cóligo do Trabalho e anda ar1. 16." da Lei n." 9)/2003; conquanto se preveja que um menor com idade inferior, que tenha concluído a escolaridade obrigatória, preste traballos leves, em certas condiçóes, art. 55.", 1.." 3, do Código do Trabalho). 'Tendo o major de dezasseis anos capacidade judiciária activa, como já se observou. F os bens que o menor (com mais de dezasseis anos) haja adquirido pelo seu trabalho são administrados pelo próprio, deles podendo dispor (cfr. art. 127.", 17." 1, al. a), e art. 1888.", n." I, at. d), do Código (ivil). Também a al. c) do n." I do ant. 127." se aplicará, no cssencial, aos maiores de dezasscis anos.

Noutro domínio, o art. 142.", n."2, al. b), do Código Penal dá poder de decisão, quanto à interupçâo da gravidez, à mulher grávida com dezasseis anos ou mais (se for mais 
nova, o conscutimento há-de ser prestado pelos seus representantes).

E, em geral, a imputabilidade penal, em raño da idade, supöe que o menor tenha de zasscis anos. Note-se ainda que os «jovens adultos», com idade compreendida cnte os derasscis e vinte e $u m$ anos, estăo sujeitos a un «regime de penas» espocial (previsto, no essencial, no Decred(1..Lei n." 401/82).

v) A partir dos dezassete anos pode set proposta uma acçáo de intendiçăo ou inabilitaçăo face ao monor (art. 130.", n." 2, 2." parte; vide infra).

${ }^{37}$ Nos termos do ant. 131." o poter paternal ou a tutela mantém se (não cessando, portanlo, nesse momento, a incapacidade) se, quando o menor atingir a maioridade, estiver pendente face a cle uma aeçäo de interdição ou inabilitaçäo (proposta nos temos do art. 130.", n."2, segunda parte).

Como noutro local expusemos (loc cit. pág. 131), o reginc adoptado náo se mosta muito feliz. Por um lado, revela se dispensível, pois o jui\% do processo de interdiçao ou inabilitação pode lançar mäo das providencias provisórias previstas no ant. 142.". Por outro, e sobretudo, cria uma uexótica» categoria (transitória, é certo) de incapares maiores nẩo interditos nem inabilitados. Actesee que, quando venha a ser decretada csa ublima medida, a incapacidade no interim referido «excede» a que corresponde à subsequente condiçäo do inabilizado. Preferivel cra a solução do Código de Seabra, onde o ant. 313." previa cue, havendo sentença de interdição ou processo pendente quando adviesse a maioridade, o juiz sobreestasse na entrega dos bens, o que restringia o âmbito de tal medida à administraçấo dos bens (e supunha que o menor estivesse sob fulcla).

Note-se que a nossa lei năo prevê a interdiçăo (ou inabiliaçäo) de menores. Se se liver presente a ideia de que a interdiçăo representa, em larga medida, a reconduçăo de um maior à menoridade (cfr. ant. 139." do (Código (Civil), será fácil entender que os menores năo possam ser interditos: a sua condiçáo já é uma condiçăo de incapacidade, a quat näo seria modificada (menos ainda pela inabilitação, visto a incapacidade do inabilitado ser bem menos profunda que a do menor). Fm conformidade, o n." 2 do att. 138.", na sua parte incial, dispöe que as intediçóes (e, por força do art. 156.", as inabilitaçoes) săo aplicáveis a maiores. I nem constitui excepça a lal regra o facto de se prever, confome já se referiu, gue a interdiçáo possa ser requerida e dectetada no ano anterior à maioridade, pois os efeitos da sentença-como se acrescenta na parte linal do preceito protraen se à altuta da maioridade.

Foram razöes de conveniencia prálica que levaram o legislador a admitir essa possibilidade, destinada a cvitar um hiato cutre a aquesisição da capacidade, por virtude da maiori-

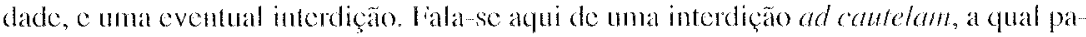
rece implicar, em todo o caso, a previsăo de cue a incapacidade persistirá na maioridade. Quanto à allura a partir da cqual pode ser proposta a açäo - . um ano antes cla majoridade-a solução legal mostra-ice adequada, tanto mais que o juir pode, na pendencia do proces so, decretar as providências necessárias, designadamente a interdiçăo provisória, para obviar a que o interditando realize qualquer acto prejudicial; no entanto, em rigor, tal eventualidade nem se chega a colocar, dado o disposto no art. $131 . "$

Porém, vistas as coisas mais de perto, a afirmaçăo inicial de que a interdeço (on inabili. tação) só se destina a maiores, porquanto careceria de sentido para un menor, deve ser entendida cam grano salis, pois assenta num pressuposto que näo é, por in ciro, exacto. 
E, por outro lado, os prazos para arguição da anulabilidade não são muito longos ${ }^{38}$ : um ano a contar do conhecimento do negócio a impugnar para as pessoas legitimadas pela al. a) do n." 1 do art. 125."; $\mathrm{um}$ ano a contar da maioridade para o menor, segundo a al. b) do mesmo preceito (o prazo de três anos, proposto no anteprojecto por GomLs DA Suvл, foi assim abreviado); um ano a contar da morte do menor, desde que ocorrida antes de expirar o prazo anterior, para os herdeiros, nos termos da al. c) $)^{39 / 40 / 4 !}$.

Com efeito, como se sabe, a incapacidade do menor nâo coincide, em toda a linha, com a incapacidade do interdito. Esta última revela-se mais ampla (referimo-nos, no essencial, à interdiçăo por anomalia psíquica c, nalguns aspectos, à inabilitaçăo com fundamento semelhante). Haja em vista a possibilidade de contratr matrimónio ou de perfilhar reconhecida aos maiores de dezasseis anos, mas inexistente para os interditos (ou inabilitados) por anomalia psíquica. Le nem mesmo no domínio dos actos patrimoniais as duas situaçôes ou estados se equivalem em absoluto. Atente-se, por exemplo, a que as excepçôes à incapacidade dos monores nâo podem aplicar-se sem adaplaçôes aos interdiros. E pondere-se ainda que a presunçăo de falta de imputabilidade estabelecida no no." 2 do art. 488." diz respeito aos menores de sete anos c aos interditos por anomalia psíquica. Seja como for, a lei conhece outros «remédios» - designadamente o disposto sobre a incapacidade acidental ou a relevância atribuida à demência notória --.. que permitirão atalhar a eventuais dificuldades com que se depare a este propósito. Nos trabalhos preparatónos apresenta-se ainda a favor da solução legal de não se prever a interdiçăo de menores o argumento - não muito convincente - de que, quod plerumque accidir, os menores de pouca idade năo reuniriam porventura condiçoes de se defenderem convenientemente nas acçós de interdição.

Contudo, mesmo no silêncio da lei, os menores emancipados hão de poder ser declarados interditos (ou inabilitados). Sendo o emancipado equiparado ao maior, adquirindo, portanto, plena capacidade, justifica se tal possibilidade. O contrátio encerraria mesmo a sua parcela de absurdo, já que se traduziria em denegar a proteçäo necessária ao incapaz emancipado (lembre-se, de resto, que a anulação, por causa distinta da falta de idade núbil, ou a dissoluçăo do casamento parecem năo implical a cessaçăo da emancipaçä́). A hipótesé é directamente contemplada (embora apenas para a interdiçấo) no ant. 414 do Codice Civile italiano.

L não lará diferença sc o emancipado casou com ou sem o consentimento dos pais, cmbora no ultimo caso haja que coordenar o regime da tutela ... de resto, recaindo a lukla sobre os pais cstes exercen o poder paternal, segundo o art. 144." do Código Civil (preceito cuja exacta interpretação suscita algumas divergências, que porén aqui não vêm a caso) - com a administração de bens instaumada nos termos do art. 1649.".

38 Nāo diferem, na sua duraçá, do prazo geral de um ano previsto no art. 287.", n." I, conquanto, nos fermos do art. 125.", n." I, possam «abrir-se» sucessivamente três prazos de um ano. Se o negócio näo liver sido cumprido, segue-se inteiramente a regra geral, ou seja, a anulabilidade é invocável sem dependência de prào, como dispõe 
o 1.." 2 do art. 287." (ressatvado pelo prómio do n." I do art. 12.5.").

${ }^{39}$ Discutido, face ao teor da parte final da al c) don." I do art. 125." "uocorrida antes deex piraro prazo referido na alínca anterior» . ćse, morrendo o menor antes de atingir a maioridade ou ser emancipado, os herdeiros dispö́m da possibilidate de requerer a anulaçäo. Parece que também nessa situageào tal direilo se deve atribuir aos herdeiros, por um argumento de paridade de razăo, e porque lal entendimento ainda se coaduna como teor literal do preceito. Aliás, quem argumenta com a impossibilidade de transmitir aos herdeiros tum direito que nunca chegon a existir para o menor, parte da premissa de que näo é este o litular do direito de anulação exercido pelos seus representantes legais. Mas, anda que se admita semelhante doutrina, nâo se aligura apropriado derivar (directa mente) do enquadramento concepluat ou dogmálico soluçós materiais ou de regime.

40 Uma questäo (fue se colocava noste contexto cra a de saber se seria preciso o concur so de ambes os pais, quando o poder paternal fosise exereido pelos dois, para requerer a anulação do acto realizado pelo menor: Hoje, o problema está resolvido no art. 12." do CPC (subsiste a questäo da eventual conlimaça do acto, para o qual mantém actuatidade a doutrima, defendida por PIRLS DF, LIMA / ANTUNES VAREA, ob. cil., anotaçaro ao ant. 124.", que entende ter, em princípio, qualquer um dos pais legitinidade para proceder à confirmạ̧ăo, excepto cm actos de mator transcendência, existindo desacondo entre os pais, cft ail. $1901 . ")$.

41 Claro que da «cascata» dos praros do n." I do art. 12.5. "pode resultar um longo período de incerteza para a contraparte. Ponto é que a «inactividade» dos representantes e do

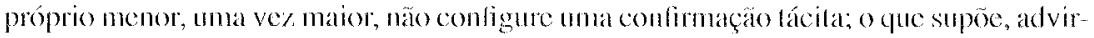
ta-se, que os representantes legais pudessem eles próprios (livemente) realizar o negó cio nessa qualidade (cli art. 125.", n." 2, in fine). Muitas veres, quando se fratar de um negócio de constituç̧ăo ou mansterência de um direito real a favor cla contraparte, esta terá entretanto adquirido por usucapião -- cujas normas, culre nós (na Alemanha porém, discule se as relaçōes das regras da usucapião com as do enriquecimento sen causa), se «sobreporão» às do art. 289." (acui, a possibilidade de considerar, nalgumas hipóteses, o neqúcio colchado pelo menor como carecendo de qualquer efeito -- «incexistente»-., segundo o at. 246.", levará a qualiticar a posse da contraparte como näo lifulada, nos termos do art. 1259.").

Ocore ainda observar que, sendo o negócio do menor anulável (e näo ineficaz, como sucede noutros sistemas jurídicos), a nossa lei täo pờ an dispor da contraparte, o su jeito passivo do direito de anulaçăo, $\mathbf{m}$ meio para fauer cessar o estado de incerteza no tocante à «sorte» do negócio, por exemplo, atraves de uma interngatio, associada à fixação de um praro, ou a simples revogaçăo ou rejeiçăo do negócio (previstas, no caso de inelicácia derivala da lalta de poderes, no ant. 268. ", n." 3 e n." 4 ; como já se referiu supra, hal possibilidade está expressamente contemplada no direito holandês, năo obstante também á́ o negócio celebrado pelo menor ser anulável).

Com cicito, a rejeição do negócio cstará afastada, pois traduzit-sc-ia, em último termo, na «inversão» do sistema legal, subvertendo desse modo a disciplina consagrada no art. 287.", n." I, que atribui legitimidade para a arguç̧ăo da anulabilidade apenas às pessoas em cujo interesse a lei a estabelece (e isto, tanto mais quanto o legislador optou peto sistoma da anulação ope iudicis). No que respeita à possibilidade de recurso à interpel 
Uma derradeira faceta da tutcla dat contraparte, em desfavor do menor, parece decorrer das regras do art. 28\%." sobre a restituição, por força da anulação do negóció, das prestaçóes efectuadas. A protecção do outro contraente resultará agora de, a ser impossível a restituição da prestação realizada, em virtude de o menor a ter consumido, deteriorado, destruído ou dela disposto, haver lugar à restituiçáo do seu valor'? Nem, tão pouco, se atender às regras do enriquecimento sem causa ${ }^{43}$, designadamente ao limite para a obrigação de restituir estabelecido no n." 2 do art. 479." (que, a julgar-se aqui aplicável, seria todavia, por vezes atenuado, nos termos do art. $480 . "$, a conceder-se relevância ao conhecimento do menor).

Latio, cla atigura se igualmente de recusar, desde logo pelo diferente valor que teria aqui o silêncio da contraparte ... a convalidação do negúcio e náa a negaçăo da sta cficácia. Cfr., solbre isto, (i. CIAN, RDCiv, 1973, págs. 538 e ss., autor que, sen se relerir no contanto dircelanente às hipoteses de incapacidade, sugere, para obstar ao exercício posterior do direito de anulação, o recurso à figura do abuso de direio, na forma da Verwirkung - tal figura assumiria relevo sobretudo em presença de unta imerrogatio da contraparte (jue, em conexão com a inactividade do «interrogado», poderia, decorrido certo tempo, lazer surgir uma confiança digna de tutela na validade do negócio. Fi essă sugestão parece-nos de acolher, também para o dircito português, quando menos nas hipóteses de un negócio unilateral recepticio realizado pelo menor (pense-se nal resolução ou denúncia de um contrato), onde a necessidade de proteçäo da contraparte se forna ainda mais premente. Ou pode até bem sustentar-se, em certos casos, que estas declaraçōes do menor näo produzem, tout court, cfeito (cventualmente con base numa analogia com o previsto no art. $260.0^{\circ}$ ).

$\Lambda$ năo estar o contrato cumprido, a anulabilidadé é suscept f́vel, segundo o art. 287.", n. ${ }^{\circ} 2$, de ser invocada a fodo o tempo, mas a contraparte disporá decerto de uma possibilidade de pôr termo ao estado de incertèa, pedindo judicialmente o cumprimento do negócio. Pois, tendo o vício cessado ou kndo havido conluecimento dele, năo duvidamos que a sua não invocaçấo, na acção en causa, pela parte legitimada the preclude, nos termos gerais do caso julgado, a possibilidade de invocá to posterionnente; neste sentido, se interpretamos correctamente o seu pensamento, AN'I'UNLS VAREL A / J. M. BBEZIERRA/ SAMPAIOE NORA, Mamual de Processo Civil, Coimbra, 1985, pág. 717.

${ }^{42}$ Inexistindo nat nossa tei um preccilo semelhante ao ant. 1443 do Codice Civile on ao atr. 1312 do Code Civil francês, contendo regras próprias para a restituiçấo da presta ६̧ăo pelo menor, o entendimento referido parece impor-se (tenhal-se en conta, porém, a remissäo para os arts. 1269." e seguintes, contida no n." 3 do arr. 289." - cujo alcance, e termos en yue se relaciona com on no." I do mesmo preceito, esta, de resto, longe de ser claro). lixprimimo-nos, no entanto, em termos dubitativos, na medida em que semellaunte soluçâo contradir a finalidade de proteçăo do menor, como já se assinalou para o dircio alemão a propósito da «Satdotheorie». 
Contudo, aqui há ainda que levar con conta a «interterencia» do disposto ne art. 764.", relativamente à capacidade para realiza e receber a prestaçöo (cfr ainda n." I do art. 58." do Código do Trabalho, que, aparentemente a menos que se entenda ser tal disposiçáo apenas aplicável se o menor näo tiver ainda 16 anos - briga com o disposto na al. d) do n." I do ant. 1888."). Nos termos do ar. 764.", os representantes legais poderäo pedir a amulaçäo da prestaçăo realizada pela contraparte e novo cumprimento se aquela măo ti. ver chegado ao seu poder, nem o palrimónio do menor se houver enriquecido (porém, $c$ delensável a doutrina de que o ant. 764." só se aplica ao cumprimento de uma obrigaçáo assumida validanconte pelos representantes legais do menot, on, noutros casos, quando a incapacidade for posterior à assumçăo da obrigaçäo entrelanto cumprida).

Em lodo o caso, desse modo, obter-se-á um resultado bem diverso do que derivaria da amulaço do negócio (donde emergiram as obrigaços cumpridas). f́ que, agora, este manter-sc-á (porventura confirmado taciamente, pela exigência de novo cum primento), năo sendo lícito aos representantes fazer valer a respectiva invalidade e, simultaneamente, querer amular a prestaça recebida pelo menor, para assim não haver lugar à sua restituiçào, nos fermos do art. 289." Como năo poderä́o, com regra, reter a prestaçäo recebida, mas anular a prestaçáo do menor - cujo cumprimento, na normal das hipóteses, é até duvidoso que constitua un prejúro para cle, se o negócio näo for anulado, pois então ca devida (atente se, porém, em que a amulabilidade ́. invocível por via de excepcío). I ogo por isiso se compreende que nouldas ordens juridicas, onde existem preceitos semolhantes ao ant. 764." do Código Civil (no Código italiano, ants. 1190 e 1191, e no Código francês, arts. 1238 : 1241), se tcuha anda sentido necessidade de estabelecer reglas próprias, no caso de anulaça do negócio, para a restituiçäo da prestaçăo recebida pelo menor (como já acima se referia).

43 Assim, em geral, ANTUNES VARLL $\Lambda$, op. cit., págs. 448 e ss., e, cxpressamento para o caso de restituição das prestações derivada de anulação do negócio por incapacidade, GALVÃO TEL HS, Dos Contratos em geral, l isboa, 1972, págs. 218 es. 


\section{ADENDA}

Posteriormente à feitura deste estudo, surgiu a 4." edição da Teoria Geral do Direito Civil de Carios Albirito Mota Pinto (Coimbra, 2005, 4." Edição por Antóno Pinto Monteiro e Paulo Mota Pinto), remodelando um Manual de imprescindivel referência em toda a matéria de Direito Civil.

Tâa-pouco se considerou, por à altura ainda não se ter tido acesso a tal obra, Tratado de Direito Civil Portuguess, I, Parte Geral, Tomo III - Pessoas, de Anjónio Menezas Corbiro (Coimbra, 2004). E, de Sónin Moreirs, Autonomia do Menor no Exercício dos seus Direitos, SI, 2001 , págs. 159 e ss. Omissões irremissíveis que mais empobreceram o conteúdo de texto agora publicado. 